\title{
Chemokine function in periodontal disease and oral cavity cancer
}

\author{
Sinem Esra Sahingur ${ }^{1,2 *}$ and W. Andrew Yeudall ${ }^{3,4,5 *}$ \\ ${ }^{1}$ Department of Periodontics, Virginia Commonwealth University, Richmond, VA, USA, ${ }^{2}$ Department of Microbiology and \\ Immunology, Virginia Commonwealth University, Richmond, VA, USA, ${ }^{3}$ Department of Oral and Craniofacial Molecular \\ Biology, Virginia Commonwealth University, Richmond, VA, USA, ${ }^{4}$ Department of Biochemistry and Molecular Biology, \\ Virginia Commonwealth University, Richmond, VA, USA, ${ }^{5}$ Massey Cancer Center, Virginia Commonwealth University, \\ Richmond, VA, USA
}

The chemotactic cytokines, or chemokines, comprise a superfamily of polypeptides with a wide range of activities that include recruitment of immune cells to sites of infection and inflammation, as well as stimulation of cell proliferation. As such, they function as antimicrobial molecules and play a central role in host defenses against pathogen challenge. However, their ability to recruit leukocytes and potentiate or prolong the inflammatory response may have profound implications for the progression of oral diseases such as chronic periodontitis, where tissue destruction may be widespread. Moreover, it is increasingly recognized that chronic inflammation is a key component of tumor progression. Interaction between cancer cells and their microenvironment is mediated in large part by secreted factors such as chemokines, and serves to enhance the malignant phenotype in oral and other cancers. In this article, we will outline the biological and biochemical mechanisms of chemokine action in host-microbiome interactions in periodontal disease and in oral cancer, and how these may overlap and contribute to pathogenesis.

Keywords: chemokine, periodontitis, inflammation, oral cancer, host-pathogen interactions, Toll-like receptor

\section{Introduction}

The human body is constantly under assault from a plethora of environmental factors that includes chemical, physical, and microbiological agents. In turn, cellular mechanisms have developed to combat these noxious stimuli, and cells of the innate immune system are central players. Sophisticated molecular regulatory pathways exist to coordinate the host response to bacterial infection and other microbiological challenges. Innate immunity also plays a fundamental role in the pathogenesis of malignant disease, acting as a surveillance mechanism to prevent tumor establishment. On the other hand, the cellular immune response is now recognized as a key promoter of tumor progression and metastasis through potentiation of chronic inflammation at tumor sites. Today, it is widely accepted that deregulated inflammation within the cellular microenvironment is one of the key elements driving tumorigenesis (1-4). Therefore, how immune and inflammatory processes are regulated and how they may result in different outcomes to the host are intriguing questions that are beginning to be understood in some detail.

The oral cavity is home to a diverse microbial community of more than 700 microbial species including commensal and opportunistic bacteria, viruses and fungi living in a symbiotic relationship with each other and the host immune system (5-7). The host-microbiome interactions at the oral mucosal surface are critical to maintain periodontal tissue homeostasis, and the balance between 
microbial cell turnover and host pro-inflammatory and antiinflammatory responses eventually determines the clinical outcome. Deregulated host immune responses resulting from environmental and systemic exposures (e.g., smoking, obesity, stress, aging, diabetes), host genetic, and epigenetic defects and/or dysbiotic oral microflora subverting the host defense mechanisms lead to chronic periodontitis (8-13). Thus, today it is believed that although microbial insult initiates the periodontal disease, deregulated immune response mechanisms determine the progression of the lesion and the extent of tissue destruction.

Periodontal disease affects $47 \%$ of the population (14). It is defined as inflammation of the periodontium involving the supporting tissues of the teeth and it is characterized by loss of epithelial attachment, connective tissue, and alveolar bone. Chronic periodontitis also serves as a constant reservoir of inflammatory mediators and microbial products that can act upon host tissues. Thus, besides its destructive local effects, persistent forms of the disease are also associated with several systemic conditions, including cardiovascular diseases, adverse pregnancy outcomes, rheumatoid arthritis, diabetes, and pulmonary diseases (15-21).

Emerging evidence also suggests a link between periodontitis and oral cancer, the rationale being that chronic inflammation is a major factor in both diseases $(22,23)$. The ability to re-route immune cells to a site of infection within the body relies in large part on the action of chemotactic cytokines, or chemokines. These are small polypeptides that are secreted into the microenvironment, and which serve to recruit leukocytes and other immunological mediators to their point of action, such as periodontal inflammatory foci. However, as well as these functions, some chemokines and their receptors have been implicated in cancer development and progression by promoting cell proliferation, motility, angiogenesis, and metastatic spread (3).

In this review article, we will outline the pathogenesis of periodontal disease and oral cancer and the plausible biological mechanisms that may link these, focusing on chemokine ligand and receptor function, and how this might promote tumorigenesis through modulation of the microenvironment.

\section{Periodontal Disease Pathogenesis}

The development and progression of periodontitis is a complex process initiated by a dysbiotic polymicrobial insult and involves multiple host cells of myeloid and non-myeloid origin including oral keratinocytes, neutrophil polymorphs (PMNs), macrophages, monocytes, dendritic cells, osteoblasts, and osteoclasts. These cells possess cytosolic, membrane-associated, and secreted pattern recognition receptors (PRRs) including toll-like receptors (TLRs), NOD-like receptors (NLRs), RIG-I-like receptors (RLR), and Ctype lectin receptors, which can engage with periodontal microbial associated molecular patterns (MAMPs) [e.g., lipopolysaccharide (LPS), lipoproteins, fimbriae, BspA, nucleic acids] and damage/danger associated molecular patterns (DAMPs) (e.g., nucleic acids, fibrinogen, heat-shock proteins). This interaction releases inflammatory mediators that aid in the development of an efficient innate immune response to eliminate the pathogen and coordinate development of an adaptive immune response. Although activation of the immune system is crucial to combat microbial insult, deregulated, persistent immune responses due to factors that are still not completely understood result in chronic inflammation, eventually leading to periodontal tissue destruction (24).

In its most general classification, periodontal disease can be categorized as either gingivitis or periodontitis. Gingivitis defines the inflammation of gingival tissues without alveolar bone loss, whereas periodontitis is accompanied by destruction of alveolar bone. Periodontal disease progression follows four histological stages: initial, early, established, and advanced (25). These definitions are based on the distinctive histological features of the pathological site with regard to the cells and the extent of tissue destruction involved. However, it is important to note that disease progression is a dynamic and highly interactive process where there is overlap between each stage, with common cells and inflammatory mediators.

The initial sequela to the polymicrobial insult is an acute inflammatory response with increased vascular dilation and blood flow. There is activation of complement and kinin systems and arachidonic acid pathways. There is also increased PMN migration toward the lesion due to chemotactic stimuli originating both from microbial cells as well as host-derived inflammatory mediators. These include IL-8 (CXCL8), complement components C5a and C3, and leukotrines. Some collagen loss is also apparent. The character and intensity of the inflammatory response determine whether the initial lesion resolves rapidly, with restoration of the tissue to a normal state, or whether it evolves into a chronic inflammatory lesion.

Early lesion is characterized by accentuation of the features of the initial lesion with increased vascularization, accumulation of more PMNs and lymphocytes (mainly T-cells), as well as continuous activation of complement and arachidonic acid pathways. Macrophages, plasma cells, and mast cells start to appear at the site of acute inflammation. These cells produce pro-inflammatory mediators including IL- $1 \beta$, IL-6, IL-8, IL-17, and TNF- $\alpha$, which may exacerbate the inflammatory response and promote progression to more advanced stages of disease. There is further loss of the collagen fiber network around the inflammatory infiltrate due to activation of the local immune system.

As the disease progresses into the established phase, there is a transition from an acute to a chronic state. The manifestations of early and initial changes still persist, along with the appearance of B-lymphocytes and continuingly increased numbers of PMNs, macrophages, monocytes, and T-cells. There is also the presence of extravascular immunoglobulins in the connective tissue and in the junctional epithelium. In the established lesion, which is clinically diagnosed as chronic gingivitis, there is substantial loss of gingival extracellular matrix due to increased collagenase activity and activation of the local immune system, but without bone loss.

The advanced lesion constitutes the final stage of the transition to periodontitis. At this stage, there is progression of inflammation to involve the alveolar bone. Production of inflammatory mediators such as cytokines, chemokines, arachidonic acid metabolites (prostaglandins), and complement proteins by activated PMNs, macrophages, monocytes, lymphocytes, fibroblasts, and other host cells can cause oxidative damage by promoting the release of tissue-derived enzymes such as matrix metalloproteinases (MMPs). Furthermore, cytokines can act on stromal and 
non-stromal cells causing increased expression of receptor activator of nuclear factor kappa-B ligand (RANKL) while decreasing osteoprotegerin (OPG) production. If the inflammation is not resolved, destruction of extracellular matrix and irreversible alveolar bone loss occur.

In summary, a polymicrobial insult initiates the periodontal disease process while the progression and clinical presentation of the disease involve complex interactions between host cells and the oral microbiome, triggering persistent inflammation, which eventually destroys the local tissues and further impacts distant sites due to the continuous access of inflammatory mediators and microbial components into the systemic circulation. The biological and biochemical pathways that may link chronic periodontitis with various systemic diseases are reviewed elsewhere (15-21).

\section{Pathogenesis of Oral Squamous Cell Carcinoma}

Squamous cell carcinoma is the most frequently occurring malignancy of the oral cavity and adjacent sites, representing over $90 \%$ of all cancers. Worldwide, 200,000 new cases of oral cavity and lip cancer are diagnosed annually, with around 98,000 deaths (http://globocan.iarc.fr/Pages/fact_sheets_population.aspx). The predominant etiological factors for oral cavity cancer are alcohol and tobacco use, with carcinogens impacting on the oral mucosa to create a field that is predisposed to undergo malignant transformation, so-called "field cancerization." Although, with early detection, "cure" rates may be as high as $50 \%$, most lesions are diagnosed at a late stage and have a much poorer prognosis due to locoregional or distant spread, with 5-year survival as low as $16 \%$. Disappointingly, clinical outcomes have not improved significantly in decades, in spite of advances in surgical, chemotherapeutic, and radiotherapeutic management, as well as the advent of targeted therapies.

The molecular pathogenesis of oral cavity cancer is, in many cases, the result of dysregulation of common signaling pathways that actively drive oncogenesis, on a background of tumor suppressor inactivation. The basis for this may be a combination of somatic mutations, as described recently (26), together with epigenetic and transcriptomic alterations. As just one example, hyperactivation of epidermal growth factor receptor (EGFR) signaling through receptor overexpression, or mutation of either the receptor or downstream signaling components, can lead to enhanced cell proliferation and motility, thereby contributing to tumor growth and metastasis. Inactivation of the P53 and CDKN2A tumor suppressors also occurs with high frequency in oral cancer. In addition to molecular dysregulation as a result of chemical carcinogens in tobacco and alcohol, infectious agents play a role in development and progression of oral cancer. Although considerably less frequent than in the oropharynx, human papillomaviralrelated carcinogenesis contributes to a small proportion of oral cavity cancers [around 10\%: (26)]. What is less clear, however, is a mechanism that might explain the long-standing notion that poor oral hygiene is related to OSCC development. As in other cancers, though, there is no doubt that chronic inflammatory conditions underpin oral carcinogenesis, and perturbations of cytokine- and chemokine-dependent immunoregulatory pathways are evident in oral cancer. Of course, the oral cavity is prone to a number of bacterial infectious diseases, such as periodontitis, and it is possible that oral bacteria may serve to initiate or promote tumor development, analogous to the association of gastric cancer with Helicobacter pylori infection. In fact, a number of periodontal bacteria including Prevotella intermedia, Porphyromonas gingivalis, Fusobacterium nucleatum have been associated with OSCC (27, 28) The plausible biological mechanisms, including microbial and inflammatory, that may link periodontitis and oral cancer are discussed below.

\section{Chemokines}

Members of the chemokine superfamily are secreted polypeptides, which range in molecular mass from around 5 to $20 \mathrm{kDa}$. Historically, these were named based on their function (e.g., macrophage inflammatory protein: MIP- $1 \alpha, \beta)$, but a generic nomenclature is now in use. This categorizes chemokines into four subfamilies based on the relative position of conserved cysteine residues within the polypeptide. Thus, $\mathrm{C}, \mathrm{CC}, \mathrm{CXC}$, and $\mathrm{CX}_{3} \mathrm{C}$ chemokines are recognized (Figure 1).

Chemokine ligands bind to cell surface receptors and the interactions may be unique (single ligand and single receptor) or promiscuous (single ligand/multiple receptors, or multiple ligands/single receptor). For example, IL-8 (CXCL8) binds to both high- and low-affinity receptors (CXCR1 and CXCR2, respectively), whereas CXCL5 only binds to CXCR2. Conversely, the CXCR2 receptor binds multiple CXC-chemokine ligands, whereas CXCR1 binds IL-8 exclusively. Intracellular signaling pathways

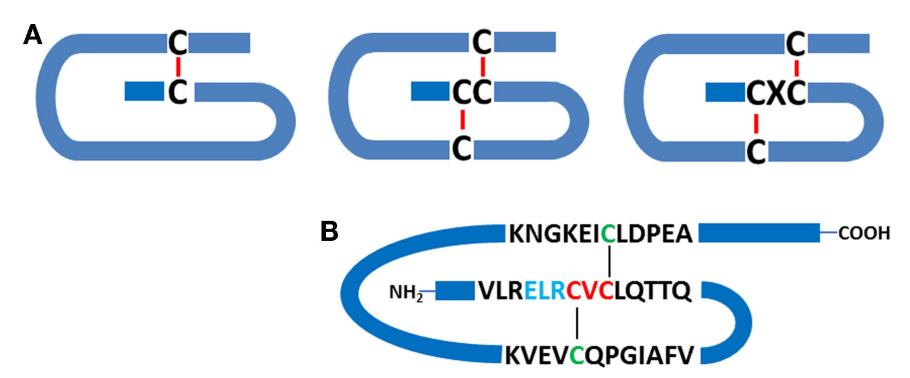

FIGURE 1 | Chemokine structure. (A) Schematic indicating the relationships between conserved cysteine residues $(\mathrm{C})$, together with intrachain disulfide bridges. C-, CC-, CXC-, and $\mathrm{CX}_{3} \mathrm{C}$ - classes of chemokines are depicted.
(B) Schematic representation of human CXCL5, a pro-inflammatory and pro-angiogenic ELR ${ }^{+}$chemokine, which contains the ELR motif N-terminal to the $\mathrm{CXC}$ consensus sequence. 
activated by chemokine ligand-receptor binding include those mediated by extracellular signal regulated kinases (ERKs), phosphoinositide 3-kinase (PI3K), AKT, small GTPases (Rac, Rho, cdc42), and NFKB family members. Thus, there is good potential for molecular crosstalk with growth factor signaling pathways.

In general, the CXC chemokines primarily activate neutrophils, whereas CC chemokines are mainly chemotactic for monocytes/macrophages and lymphocytes, and play a role in the class switching of macrophages from M1 to M2 during the transition from acute to chronic inflammation. CC chemokines are also crucial in the development of adaptive immunity by propagating lymphocyte recruitment and antigen presentation, and they play a critical role in bone metabolism by providing signals for the trafficking of osteoblast and osteoclast precursors.

Several inflammatory mediators including cytokines are abundantly expressed in the course of periodontitis (29). With regards to cancer risk, chemotactic cytokines or chemokines are of particular interest to us as they are involved in almost every stage of periodontal pathogenesis and can also be expressed in healthy sites. In addition to their role in immune cell trafficking to the site of infection, they also regulate angiogenesis, cell proliferation, apoptosis, and tumor cell homing. The next section will give a brief overview of chemokines involved in chronic periodontitis. Later, we will discuss how they may modulate the oral microenvironment to promote cancer progression.

\section{Chemokines in Periodontal Disease}

As noted above, the host immune response to infection is largely regulated by cytokine signals that drive initiation and progression of the inflammatory process. Their involvement with periodontal disease and their possible systemic effects have been wellreviewed elsewhere $(24,30)$. Here, we will focus specifically on chemokines that are expressed in periodontal tissues and their potential modulatory role in the tumor microenvironment.

Chemokine expression can be triggered by MAMPs, DAMPs, inflammatory mediators, host factors, and mechanical stress. In the oral tissues, chemokines can be synthesized by a variety of cell types including fibroblasts, osteoblasts, endothelial, epithelial and mast cells, PMNs, lymphocytes, and monocytes/macrophages. Thus, they play a major role in immune cell trafficking to sites of periodontal infection (29).

IL-8 (CXCL8) is one of the most abundantly expressed chemokines in the oral cavity and can be detected in both healthy and periodontally diseased tissues (31-36). IL-8 is primarily produced by gingival keratinocytes, fibroblasts, endothelial cells, and macrophages in response to periodontal bacteria and bacterial components. It functions to direct cell trafficking, mainly PMNs, to the site of infection. Inflammatory cell recruitment eventually results in more cytokine production, thus contributing directly to progression of the periodontal lesion. Although clinical studies consistently show that increased IL-8 levels are associated with periodontally diseased sites (31-36), in vitro studies with individual periodontal pathogens show variations in IL-8 production depending on the bacteria and the cell type being studied. For example, $P$. gingivalis, a key-stone periodontal pathogen, shows a distinct ability to manipulate local immune responses for its survival, either by increasing or suppressing IL-8 production (37-42). These unique features, possessing both pro- and antiinflammatory properties, give $P$. gingivalis the ability to create a dysbiotic environment and escape immune surveillance. However, the possible biological mechanisms through which this bacterium may promote tumor development have yet to be investigated in depth.

Besides being a major chemoattractant for PMNs, IL-8 can also affect bone metabolism through its direct actions on osteoclast differentiation and activity by signaling through the highaffinity CXCR1 receptor (43). Additionally, the results of a metaanalysis investigating the risk of oral cancer in patients with polymorphisms of the IL-8-251A $>$ T locus revealed that Caucasian populations harboring the AA genotype had a higher risk of developing malignancy (44), whereas a separate meta-analysis also indicated increased risk for individuals with either the AT or AA genotype (45). The functional significance of this finding is yet to be determined. Thus, many periodontal bacteria and bacterial components can trigger IL-8 production in different cells of the periodontal tissues and IL- 8 is considered as one of the major chemokines associated with periodontal disease. Therefore, future investigations are warranted to elucidate the biological mechanisms triggered by IL- 8 that modulate the oral environment and increase susceptibility for tumor development and/or progression.

Besides IL-8, another CXC-chemokine, CXCL12 is reported to provide trafficking signals for osteoblast and osteoclast precursors, and it also enhances the activity of MMP9 in osteoclasts, promoting bone resorption. CXCL10, which is a chemoattractant for activated Th1 cells, is found in inflamed gingival tissues (29) and is expressed by human gingival fibroblasts (46) in response to interferon- $\gamma$, tumor necrosis factor- $\alpha$, and IL-1 $\beta$, suggesting this as a mechanism to recruit Th1 cells to inflammatory foci in periodontitis. Notably, these authors also found that the antiinflammatory cytokine IL-10 represses CXCL10 expression. Blymphocytes are also plentiful in periodontal lesions, and it is not surprising that CXCL13, which is chemoattractant for Bcells, is highly expressed in diseased tissues, suggesting a role for this chemokine in the local humoral response to periodontal pathogens.

CC-chemokines are also documented to play various roles in the pathogenesis of periodontitis. CCL2 and CCL3 are chemotactic for monocytes and lymphocytes, CCL4 is chemotactic for $\mathrm{CD}^{+}{ }^{+} \mathrm{T}$ cells, and CCL5 attracts Th1 cells. All of these ligands have been found at higher levels in chronic periodontitis patients compared to healthy controls, and are associated with disease severity (47-49). Increased expression of the CC-chemokines, CCL2, and CCL20 was also correlated with increased numbers of dendritic cells (50). Macrophages are one of the key cell types found in large numbers in periodontitis lesions, and are involved in phagocytosis of pathogens and production of inflammatory mediators. However, increased accumulation of macrophages and deregulated inflammatory responses can disrupt tissue homeostasis, thereby contributing to periodontal disease. Like IL-8, CCL3 and CCL5 also play roles in bone metabolism and induce migration and activation of osteoclasts. Thus, it is likely that they exacerbate periodontal disease severity. 
CCL20 is involved in Th17 cell recruitment and may promote periodontal disease. Hosokawa and coworkers (51) demonstrated that IL-22 increased CCL20 production in human gingival fibroblasts through an NF- $\kappa \mathrm{B}$-dependent mechanism when the cells were pre-challenged with IL-1 $\beta$. Similarly, IL-6-stimulated periodontal ligament cells showed elevated secretion of CCL20 in a STAT3-dependent manner (52).

CCR4 is a high affinity receptor for both CCL17 (53) and CCL22 (54) and is expressed at higher levels in chronic periodontitis, as well as being associated with higher levels of the anti-inflammatory IL-10 in the periodontium (55). CCL17 and CCL22 are also expressed in diseased periodontium, and it may be possible that expression of these ligands serves to limit periodontal disease severity by attracting Th2 and Treg cells. Stimulation of human gingival fibroblasts with a combination of TNF- $\alpha$ and IL4/IL-13 was found to increase expression of CCL17. While CCL17 expression was inhibited by Escherichia coli LPS and Pam3CSK4, which are activators of TLR4 and TLR2 signaling, respectively, in TNF- $\alpha /$ IL-4 stimulated gingival fibroblasts, CpG DNA (which activates TLR9) enhanced CCL17 production induced by TNF$\alpha /$ IL-4. Thus, it remains unclear whether CCL17 is likely to reduce or exacerbate inflammation in periodontitis.

\section{Chemokines in Oral Cancer}

Although the normal function of the chemokine system is immunomodulation, there is an ever-increasing body of evidence that documents subversion and dysregulation of this intricate network of signaling molecules during the onset and progression of malignant disease. Overall, altered chemokine function in cancer promotes cell survival, enhanced proliferation, neovascularization, motility and metastasis in multiple tumor types, and this is comprehensively reviewed elsewhere. Several studies have implicated a number of chemokines and their receptors in oral squamous cell carcinogenesis [reviewed in Ref. (56)]. Most frequently, this appears to involve chemokines of the CXC subgroup such as CXCL1 (Gro- $\alpha$ ), CXCL8 (IL-8), CXCL5, and CXCL12 (SDF-1). IL-8 has long been recognized as an autocrine regulator of OSCC growth (57), and it also contributes to enhanced cell motility (58). Indeed, salivary IL- 8 has been proposed to be a discriminative biomarker for oral cancer (59). The closely related CXCL5 protein, normally chemotactic for neutrophils, has also been shown to drive oral cancer cell growth and motility as well as enhance tumor angiogenesis. Moreover, in vivo studies demonstrated complete inhibition of the tumorigenic phenotype when CXCL5 expression was suppressed in OSCC cells (60). Studies by Khurram and colleagues (61) reported elevated expression of both CXCR1 and CXCR2 in oral cancer. The former is a highaffinity IL-8 receptor, and the latter is a low-affinity IL-8 receptor that is also able to bind a number of CXC-chemokines including CXCL1, CXCL2, CXCL3, CXCL5, and CXCL6. These authors reported coincidental activation of signaling pathways by IL-8 and CXCL1, suggesting that simultaneous stimulation of cancer cells by multiple chemokines in the tumor microenvironment is likely to occur.

The CXCL12 (SDF-1)/CXCR4 axis also appears to play critical roles in OSCC development and progression. Expression of the
CXCR4 receptor is elevated in tongue cancers (62), with metastatic tumor cells expressing higher levels than non-metastatic. This is consistent with the homing model proposed by Muller et al. (63), where tumor cells that overexpress a chemokine receptor migrate preferentially to organs that express the cognate ligand via a chemokine gradient. Perhaps of high relevance to this review, bacterial products have been reported to increase the expression of CXCR4 on oral cancer cells (64).

SDF-1/CXCR4-driven invasion of oral cancer is reported to be dependent upon NFkB signaling $(65,66)$. Further studies have demonstrated release of the CXCR4 ligand, SDF-1, from bone cells adjacent to the tumor. This has been proposed to contribute to bone turnover as a result of CXCR4-mediated upregulation of IL-6, which is then secreted by the tumor cells to stimulate osteoclastogenesis (67), thereby enhancing tumor invasion. Studies by Oue et al. (68) provided further evidence of a role for IL-6 and RANKL in OSCC, mediated at least in part through a CXCL2dependent mechanism, as the effects were diminished by a CXCL2 neutralizing antibody.

Of course, there is always the potential for repression of malignant properties by chemokines, as some have noted anti-tumor effects. The chemokine CXCL14, also known as BRAK to signify the tissues (breast and kidney) from which it was originally isolated (69), was shown to be expressed in normal squamous epithelium but reduced or absent in malignant oral tissues (70), and is also repressed by EGFR signaling (71). Ectopic expression of CXCL14 completely blocked OSCC growth in vivo (72), suggesting that loss of expression may contribute significantly to the pathogenesis of oral cancer.

The CC-class of chemokines has also been implicated in oral carcinogenesis. Studies by Ferris and coworkers (73) documented loss of CCR6 and upregulation of CCR7, the receptor for CCL19 and CCL21, on oral cancer cells, and demonstrated that this was related to lymph node metastasis. CCL5-CCR5 signaling is reported to enhance OSCC motility, as well as increasing production of the gelatinase, MMP9 (74). An interesting study from $\mathrm{Li}$ and colleagues (75) demonstrated CCL2 production by cancerassociated fibroblasts (CAFs), which stimulated production of reactive oxygen species (ROS) in cocultured oral cancer cells. In turn, ROS promoted further CCL2 production in CAFs, thus generating a mutually beneficial microenvironment in which both tumor cells and fibroblasts could thrive.

Evidence is also present in the literature to support a role for $\mathrm{XCR} 1$, a receptor for lymphotactin (XCL1), in epithelial biology. Khurram and colleagues (76) reported expression of this receptor on oral cancer cells as well as on normal keratinocytes and neutrophils. Based on immunohistochemical analysis, low but detectable expression in normal mucosa was primarily restricted to the basal layer. In contrast, XCR1 expression was more marked in oral cancer tissues and could also be found in metastatic deposits. Interestingly, positive staining was observed in lichen planus, a potentially premalignant condition of immunological etiopathogenesis. Stimulation of XCR1 activity led to elevated expression of the gelatinases MMP2 and MMP9, which was more marked in cancer cells compared to normal keratinocytes. Moreover, cancer cells expressed MMP7, which was not observed in normal cells treated with lymphotactin. Potentially, then, XCR1 
may mediate matrix remodeling in oral epithelium, and potentiate migration and invasion in malignant disease.

\section{Potential Biological and Biochemical Mechanisms Linking Periodontal Disease and Oral Cancer}

It has been estimated that $15-20 \%$ of tumors are driven by chronic infection and inflammation, and that individuals who are prone to chronic inflammatory disorders have an increased risk of cancer development (77). Recent advances suggest that the tumor microenvironment plays an important role in the initiation and progression of malignant disease (78). This can be mediated through biological factors related to genetic and epigenetic makeup of the cancer cells or through interaction of tumor cells with the surrounding milieu, which is composed of cells and soluble molecules of both microbial and host cell origin as well as extracellular matrix.

Several studies have reported an association between chronic periodontitis and cancer both in the oral cavity as well as at distant sites $(22,79,80)$. Studies that have investigated the association between periodontal disease and oral cavity cancer are summarized in Table 1. While plausible biological mechanisms exist that can link the two diseases (Figures 2 and 3), the exact etiology is yet to be established. Tezal and coworkers reported that patients with periodontitis had a 5.23-fold increased risk of tongue cancer for each millimeter of alveolar bone loss (81). A further casecontrol study suggested a similar trend, with a stronger association between periodontitis and oral cavity cancer, compared to oropharyngeal or laryngeal tumors (82), and this was still noticeable in non-smokers. In addition, SCC lesions were more likely to be poorly differentiated in periodontitis patients compared to patients without periodontitis. Furthermore, a study of base-oftongue cancers indicated that patients with HPV-positive tumors had greater bone loss than those with HPV-negative lesions (83), with the authors concluding that chronic periodontitis may influence HPV infection. Interestingly, a cross-sectional study revealed a relationship between alcohol consumption (a recognized risk factor for oral cavity cancer development) and clinical attachment loss (84). Thus, it may be possible that alcohol promotes oral carcinogenesis through multiple mechanisms, including potentiation of periodontal inflammation. As outlined above, constant polymicrobial insult and production of inflammatory mediators drive the initiation, progression, and persistence of periodontitis lesions. Chronic exposure to microbial and host-derived products can likely modify the oral microenvironment and possibly distant tissues, promoting carcinogenesis or at least increasing susceptibility.

TABLE 1 | Studies investigating the link between oral cancer and periodontal disease.

\begin{tabular}{|c|c|c|c|c|}
\hline Author & Study design & Oral health criteria & Study population & Results \\
\hline $\begin{array}{l}\text { Bundgaard } \\
\text { et al. (85) }\end{array}$ & Case-control & Missing teeth & $\begin{array}{l}161 \text { patients and } 400 \text { controls } \\
\text { (Denmark) }\end{array}$ & $\begin{array}{l}\text { Significantly increased risk of developing oral SCCA } \\
\text { for patients with fewer than } 15 \text { teeth }\end{array}$ \\
\hline $\begin{array}{l}\text { Rezende } \\
\text { et al. (86) }\end{array}$ & Case-control & $\mathrm{CPITN}^{\mathrm{a}}$ and $\mathrm{DMFT}^{\mathrm{b}}$ & $\begin{array}{l}50 \text { patients and } 50 \text { controls } \\
\text { (Cuba) }\end{array}$ & $\begin{array}{l}76 \% \text { of subjects in cancer group showed greater than } \\
6 \mathrm{~mm} \text { pockets compared to } 10 \% \text { of control group }\end{array}$ \\
\hline $\begin{array}{l}\text { Garrote } \\
\text { et al. ( } 87)\end{array}$ & Case-control & Missing teeth & 200 patients and controls (Cuba) & $\begin{array}{l}\text { Significantly increased risk of oral cancer for patients } \\
\text { missing } 16 \text { or more teeth }\end{array}$ \\
\hline $\begin{array}{l}\text { Hiraki } \\
\text { et al. (88) }\end{array}$ & Case-control & Missing teeth & $\begin{array}{l}429 \text { patients and } 10,480 \text { controls } \\
\text { (Japan) }\end{array}$ & $\begin{array}{l}\text { Significantly increased risk of head and neck cancer } \\
\text { with decreased number remaining teeth }\end{array}$ \\
\hline $\begin{array}{l}\text { Marshall } \\
\text { et al. (89) }\end{array}$ & Case-control & Missing teeth & $\begin{array}{l}290 \text { patients and controls (United } \\
\text { States) }\end{array}$ & $\begin{array}{l}\text { Significantly increased risk of oral cancer with loss of } \\
11 \text { or more teeth }\end{array}$ \\
\hline $\begin{array}{l}\text { Michaud } \\
\text { et al. (90) }\end{array}$ & Cohort & $\begin{array}{l}\text { Self-reported history of periodontal } \\
\text { disease (confirmed by radiographs } \\
\text { and missing teeth) }\end{array}$ & 118 patients (United States) & $\begin{array}{l}\text { No significant increase in risk for oropharyngeal } \\
\text { cancer with history of periodontal disease or } \\
\text { increased number of tooth loss }\end{array}$ \\
\hline $\begin{array}{l}\text { Rosenquist } \\
\text { et al. (91) }\end{array}$ & Case-control & Missing teeth & $\begin{array}{l}132 \text { patients and } 320 \text { controls } \\
\text { (Sweden) }\end{array}$ & $\begin{array}{l}\text { Significantly increased risk of oral and oropharyngeal } \\
\text { cancer for missing over } 20 \text { teeth }\end{array}$ \\
\hline Tezal et al. (92) & Cohort & Clinical attachment loss (CAL) & $\begin{array}{l}131 \text { oral tumors and } 323 \text { oral } \\
\text { pre-cancerous lesions (United } \\
\text { States) }\end{array}$ & $\begin{array}{l}\text { Significantly increased risk of oral tumor and } \\
\text { pre-cancerous lesion with }>1.5 \mathrm{~mm} \text { clinical } \\
\text { attachment loss }\end{array}$ \\
\hline Tezal et al. (81) & Case-control & Alveolar bone loss & $\begin{array}{l}51 \text { cases and } 54 \text { controls (United } \\
\text { States) }\end{array}$ & $\begin{array}{l}\text { Significantly increased risk of tongue cancer with } \\
\text { increased alveolar bone loss }\end{array}$ \\
\hline Tezal et al. (82) & Case-control & Alveolar bone loss & $\begin{array}{l}266 \text { patients and } 207 \text { controls } \\
\text { (United States) }\end{array}$ & $\begin{array}{l}\text { Significantly increased risk of oral cavity SCC with } \\
\text { periodontitis }\end{array}$ \\
\hline Tezal et al. (93) & Case-control & Alveolar bone loss & $\begin{array}{l}124 \text { head and neck SCC patients } \\
\text { (United States) }\end{array}$ & Periodontitis is associated with tumor HPV status \\
\hline Wen et al. (94) & Cohort & $\begin{array}{l}\text { Medical records from insurance } \\
\text { claims }\end{array}$ & $\begin{array}{l}96,375 \text { gingivitis and } 51,791 \\
\text { periodontitis cases (Taiwan) }\end{array}$ & $\begin{array}{l}\text { Significantly increased risk of oral cancer with the } \\
\text { history of periodontitis }\end{array}$ \\
\hline $\begin{array}{l}\text { Zheng } \\
\text { et al. (95) }\end{array}$ & Case-control & Missing teeth & $\begin{array}{l}404 \text { subjects and controls } \\
\text { (United States) }\end{array}$ & $\begin{array}{l}\text { Significantly increased risk of oral cancer with } \\
\text { increased missing teeth }\end{array}$ \\
\hline
\end{tabular}

${ }^{a}$ WHO guidelines of community periodontal index of treatment needs (depth of periodontal pockets on scale of 1-4).

${ }^{b}$ WHO guidelines of decayed, missing, and filled teeth. 


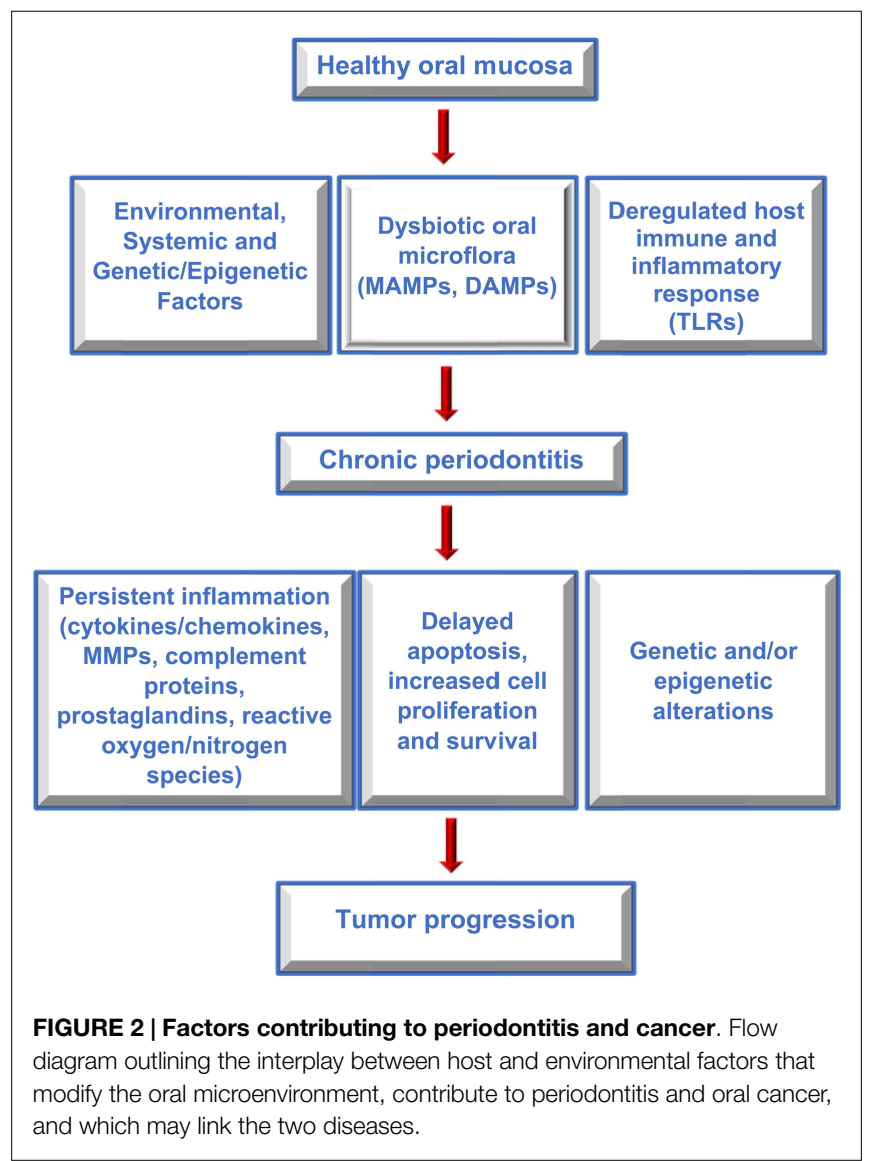

Ongoing research efforts focus on the working hypotheses that the chronic periodontitis may be linked with oral cancer risk either through direct toxic effects of the oral microbiome and associated byproducts and/or through the indirect effect of chronic oral inflammation. The next section will give an overview of potential biological mechanisms related to persistent, chronic periodontal disease that may promote cancer development in the oral cavity.

\section{The Contribution of the Oral Microbiome}

As mentioned above, a number of factors are considered to play an important role in the genesis of oral cancer (96), including tobacco and alcohol use, dietary factors such as saturated fat and fruit/vegetable intake, and microbiological agents. While tobacco and alcohol are recognized as being primary etiologic factors for oral squamous carcinogenesis, there is a worrying trend in the incidence of oral cancer in patients who have never used these agents (97), raising the possibility that other factors may have a major role in tumor progression in these subjects. Furthermore, many users of tobacco and alcohol do not develop malignant oral disease, suggesting that additional events and/or cofactors are of importance.

A diverse group of microbial species inhabit the oral cavity, including bacteria, viruses, and fungi. For many years, it has been suggested that oncogenic human papillomaviruses may contribute to oral squamous carcinogenesis (98-101), similar to their role in cervical cancer. However, more recent studies have indicated that

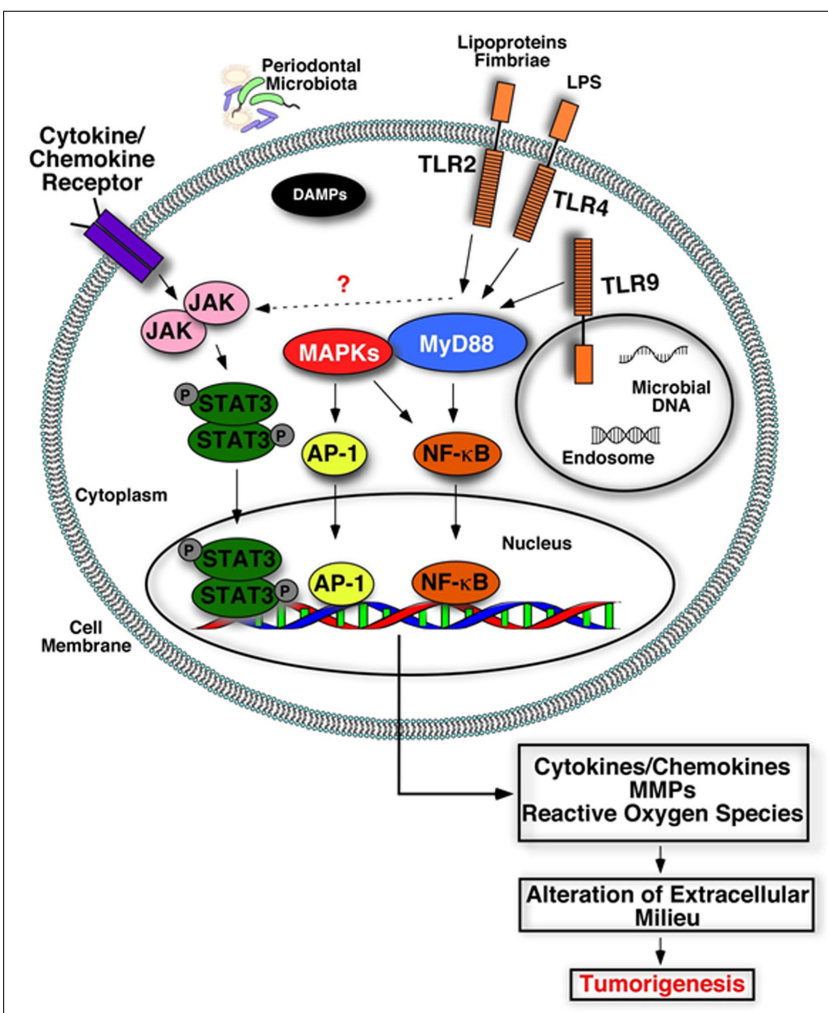

FIGURE 3 | Plausible biological mechanisms that may link deregulated inflammation and cancer. Engagement of microbial components (LPS, lipoproteins, nucleic acids) or damage-associated molecular patterns (DAMPs) with their receptors (TLRs) triggers activation of inflammatory signaling cascades and increases production of inflammatory mediators, tissue destructive enzymes (MMPs), and reactive oxygen/nitrogen species. Accumulation of these host-derived factors within the mucosa due to deregulated inflammation may alter and create a favorable oral microenvironment that promotes tumorigenesis.

HPV may be more closely related to particular subsets of disease, specifically oropharyngeal and tonsillar carcinomas (102-105).

In addition to a possible viral etiology of a subset of oral cancers, bacteria have also been implicated in tumor development. For many years, Treponema pallidum has been associated with oral squamous carcinogenesis $(106,107)$. While the incidence of syphilis has declined markedly over the last century, it may still be involved in a small number of cases (108). However, poor oral hygiene has also been documented as a risk factor for development of oral malignancy $(85,89,91,109,110)$, raising the possibility that some of the many other bacterial species present in the oral cavity may be of importance. For example, in a study of bacterial species associated with oral SCC, Nagy and coworkers reported a significantly higher number of anaerobic periodontal bacteria associated with malignant lesions compared to normal mucosa, including periodontopathogenic Prevotella and Porphyromonas species (28). Another study investigated the relationship between salivary micro-organisms and oral cancer (27). Interestingly, these authors reported increased levels of bacterial species associated with SCC, including Prevotella, Porphyromonas, and other species, and demonstrated that the levels of at least three salivary bacterial species were predictive of around $80 \%$ of SCCs. Whether 
this relationship is merely associative or indicates a role for oral bacteria in neoplastic progression remains to be determined.

The idea of a bacterial etiology for human cancer is by no means limited to the oral cavity. Indeed, it is readily apparent that $H$. pylori infection is causally associated with malignancies of gastric epithelia $(111,112)$, leading to the categorization of this organism as a WHO class I carcinogen. $H$. pylori causes inflammation of the gastric mucosa, likely by inducing gastric epithelial cells to secrete IL-8, which results in recruitment of inflammatory cells to the site of infection (113). Moreover, IL- 8 has the capacity to stimulate proliferation of epithelial cells, at least in part through transactivation of the EGF receptor (114). Further, as mentioned above, IL- 8 and other chemokines and their receptors have been implicated in tumor development and metastatic progression in a number of human malignancies (115). This may well be true for oral cavity cancers and that oral bacterial species have the capacity to induce parallel events. In fact, a recent investigation reported that increased IL-8 expression in OSCC significantly correlated with increased serum IL-8 levels and poor clinical outcomes. The study also showed that IL- 8 enhanced generation of CD163-positive M2 macrophages, and that CD163 positivity at the tumor invasion front correlated with significantly worse overall survival and disease-free survival in OSCC (116). In further support of the possible contribution of the oral microbiome to tumorigenesis, it was reported that hepatocyte growth factor (HGF) can be induced in fibroblasts by oral bacteria as well as by cytokines (117), while production of CCL20 was upregulated by Actinobacillus actinomycetemcomitans, E. coli LPS, and TNF$\alpha$ (118). This provides a link between the oral microflora and factors which are known to influence both the proliferation and migration of epithelial cells. Additionally, studies by Sakamoto and coworkers investigated bacterial colonization of oral tumors and cervical lymph nodes $(119,120)$. Viable bacteria were recovered from both tumor and lymph nodes, with involved nodes showing higher colonization than uninvolved nodes (120). It was suggested that disruption of the integrity of the epithelial layer by the primary tumor might facilitate bacterial entry and subsequent lymphatic drainage. If, indeed, oral bacteria can colonize and survive in lymph nodes, they might stimulate the production of factors that could aid survival and proliferation of any tumor cells in the immediate environment. Furthermore, the association of $F$. nucleatum, another periodontal bacterial species, with colorectal cancer also supports the notion that oral pathogens can obtain access to distant sites and may participate in tumorigenesis in other organs as well $(17,121)$. F. nucleatum is one of the most frequently identified bacteria both in healthy gingiva as well as periodontitis sites and can also induce production of cytokines and chemokines (121).

Another alternative may be that oral bacteria invade tumor cells at the primary site, influencing their biological behavior. $P$. gingivalis has the ability to invade and propagate intracellularly (122), including in gingival epithelial cells (123). It can also delay apoptosis in gingival epithelial cells through various different mechanisms, such as by activating the JAK1/STAT3/Akt pathway, downregulating caspase- 3 and caspase 9 expression, upregulating microRNAs (specifically miR-203), leading to suppression of SOCS3, preventing ATP-dependent apoptosis (124-128).
Programed cell death is one mechanism through which cells avoid replicating if DNA damage is excessive and cannot be repaired. Thus, by interfering with this key regulatory process $P$. gingivalis may promote carcinogenesis. Furthermore, $P$. gingivalis also possesses both anti- and pro-inflammatory activities thereby contributing to dysbiotic microflora (129). This feature also gives the bacterium a unique ability to manipulate the immune system for its own survival. P. gingivalis can also promote invasion of oral cancer cells by activating the ERK1/2-Ets1, p38/HSP27, and PAR2/NF- $\kappa B$ pathways to induce MMP9 (130). Increased IL6 and IL- 8 production was also reported in HSC-3 and H413 oral cancer cells in response to $P$. gingivalis challenge (131). Another important way in which $P$. gingivalis might contribute to tumor progression is through its ability to suppress angiostatic chemokines. In a key study (132), Jauregui et al. found that this bacterium could suppress the secretion of CXCL9, CXCL10, and CXCL11. Thus, the removal of their regulatory activity could promote neovascularization and enhance tumor growth.

While the bacterial etiology of periodontitis is well established, the contribution of viruses to the pathogenesis of periodontal disease has also been supported by a number of studies (133-137). It is likely that viral/bacterial interactions in the oral cavity can further modulate the oral microenvironment. For example, it has been shown that Herpes simplex virus type 1 (HSV-1), EpsteinBarr virus (EBV), and human cytomegalovirus-infected periodontitis lesions harbor elevated levels of periodontal pathogens. It was also reported that EBV can reside in gingival epithelial cells, which may serve as an oral reservoir for virus infected cells. Importantly, epithelial EBV infection was significantly increased in chronic periodontitis (138). Additionally, both HPV and EBV have been implicated in head and neck carcinogenesis. As mentioned above, a study among patients with base-of-tongue cancer suggested a synergy between periodontitis and HPV status (82), and chronic periodontitis was also associated with HPV positive tumor status in patients with incident primary squamous cell carcinoma of the oral cavity, larynx, and oropharynx (93). The biological and molecular mechanisms defining how bacterial/viral interactions modify the tumor microenvironment and lead to disease initiation or progression are poorly understood, and are an area of active investigation. A plausible possibility is the activation of innate immune sensors such as TLRs (see below). For example, TLR-2, TLR-4, and TLR- 9 can be stimulated by oral bacterial species, whereas viruses activate TLR-3, -7, -8, and 9. Thus, there would seem to be scope for synergistic activation of multiple pathways in response to different components of the oral microbiome, resulting in gene activation and production of secreted mediators into the extracellular millieu. However, this is likely to be a complicated scenario as some studies have reported that activation of specific TLRs (for example, TLR-3 and -7) may trigger apoptosis rather than pro-survival and pro-oncogenic mechanisms (139-141).

\section{The Contribution of Chronic Inflammation}

Disease progression in periodontitis is a complex process that involves the interaction of multiple components of the host immune response and the oral microbiome, as outlined above. 
The engagement of MAMPs and DAMPs with their cognate receptors releases inflammatory mediators that aid in the development of an efficient innate immune response to eliminate the pathogen and coordinate development of an adaptive immune response. However, the impaired tissue homeostasis and deregulated inflammation in periodontitis exposes the local and systemic tissues to noxious metabolic products including living and necrotic cells, cytokines, chemokines, prostaglandins, MMPs, reactive oxygen and nitrogen radicals. Accumulation of these host-derived factors may likely modulate the tumor microenvironment by causing DNA damage, promoting epigenetic and genetic alterations, increasing angiogenesis, cell survival, proliferation, migration, and inhibiting apoptosis (Figures 2 and 3). Altered cells may eventually promote production of more inflammatory mediators, further enhancing inflammation and contributing to cancer pathogenesis.

One mechanism through which host cells detect microbial challenge is through engagement of microbial components with innate receptors, specifically TLRs. These receptors can interact with components of bacteria, viruses, and fungi (142). Several cell types found in periodontal tissues express TLRs, and each receptor is involved in the sensing of distinct microbial products. TLRs are type I trans-membrane proteins composed of an extracellular leucine-rich repeat (LRR) domain involved in ligand recognition, a trans-membrane domain, and a tollinterleukin 1 receptor (TIR) domain involved in signaling. The signaling pathways activated by TLRs engage adaptor molecules that are recruited by TIR/TIR domain interactions. These include the myeloid differentiation primary response gene (MyD88), the TIR domain-containing adaptor protein (TIRAP, also known as MAL), TIR domain-containing adaptor inducing interferon- $\beta$ (TRIF), and the TRIF-related adaptor molecule (TRAM). MyD88 is essential for signaling through all TLRs, except TLR3, and is involved in early activation of NF- $\mathrm{KB}$ and MAPKs, leading to proinflammatory gene expression. As well as immune cells and oral keratinocytes, oral cancer cells also express TLRs (143-146). Thus, tumor cells or their premalignant counterparts may respond to direct stimulation by oral microbes or their byproducts, activating pro-inflammatory, pro-proliferative, and pro-migratory signaling pathways.

Of high relevance to carcinogenesis, an interesting study by Lappin and colleagues (147) determined plasma concentrations of CXCL5 and IL-6 in systemically healthy subjects with or without periodontitis, and who either did or did not smoke. They found significantly higher levels of circulating CXCL5 in smokers with periodontitis, which correlated with probing depth, attachment loss, and tobacco consumption. Given the potential function of CXCL5 as a pro-angiogenic factor (148), together with its role to promote tumor cell growth and motility (60), high circulating levels of CXCL5 could potentially act to promote tumorigenic progression in concert with local factors.

The loss of periodontal tissue integrity due to chronic inflammation aids viral and bacterial survival and persistence, as well as enhancing the inflammatory response. It is therefore plausible to hypothesize that prolonged inflammation in periodontal tissues due to activation of innate sensors by periodontal microbial products or DAMPs may promote a tumor-favorable environment by exposing the tissues to multiple cytokines/chemokines. In fact, emerging evidence also supports this concept (149). Increased expression of host innate receptors has been reported in periodontitis lesions compared to healthy sites (150-153). Among these, TLR9 has been implicated in oral squamous cell carcinogenesis (149). TLR9 is an intracellular sensor that can activate a range of cell types such as macrophages, dendritic cells, PMNs, $B$ cells, and epithelial cells through recognition of bacterial and viral DNA sequences that are released following phagocytosis. TLR9 activation can trigger production of multiple inflammatory mediators in response to periodontal pathogens, including IL-8 production from gingival epithelial cells and macrophages (154157). TLR9 expression was also reported to be significantly elevated in the tissues of oral squamous cell carcinoma as well as periodontitis, and increased receptor expression was correlated with increased tumor size and clinical stage $(153,158,159)$. In vitro studies revealed that activation of TLR9 can mediate oral cancer cell migration by up-regulating MMP2, and tumor cell proliferation by up-regulating cyclin D1 expression, both in an AP-1-dependent manner $(159,160)$. Increased IL- $1 \alpha$ and IL6 production in OSCC cells treated with a TLR9 agonist was also reported (160). It is therefore possible that TLR9 activation can contribute to tumorigenesis by enhancing inflammation and through modulating cell cycle progression. Another clinical investigation reported a strong correlation between TLR2, -4, and -9 expression and increased tumor invasion in oral tongue squamous cell carcinoma (161). This study also revealed that increased TLR9 expression correlated with advanced tumor size, while high TLR5 expression was associated with a lower tumor grade. It is important to emphasize that all of these receptors are also activated by periodontal bacteria in the course of periodontal disease and trigger production of cytokines and chemokines (162) through NF- $\kappa \mathrm{B}, \mathrm{AP}-1$, and MAPKs. Among these molecules, $N F-\kappa B$ expression and activity is often elevated in oral cancers, with protein levels gradually increasing as the lesion progresses from premalignant to invasive form (163-165). Further, aberrant function of NF- $\kappa \mathrm{B}$ has also been reported to stimulate STAT3 activation by an autocrine/paracrine mechanism in SCC, suggesting crosstalk between these signaling pathways (166). STAT3 is a critical mediator of the pro-angiogenic and immunosuppressive activities of myeloid cells in the tumor microenvironment, and it can lead to enhanced cell cycle progression and neovascularization, thus promoting tumor growth $(167,168)$. Collectively, these findings support the hypothesis that aberrant activity of multiple innate receptors and inter-related downstream signaling pathways contribute to oral tumorigenesis. Intriguingly, STAT3 and NF- $\kappa \mathrm{B}$ lie downstream of TLR-mediated inflammatory cascades including those activated by TLR-2, -4, and -9 (169). It remains to be determined whether STAT3 signaling is triggered as a result of direct stimulation of these receptors or as a result of the production of cytokines, such as IL-6, and development of a positive feedback loop.

In summary, it is likely that deregulated receptor activity within the oral cavity due to chronic periodontitis may be associated with tumor progression, possibly as a result of exposure of the mucosa to cytokines, chemokines, MMPs, and reactive oxygen (or nitrogen) radicals. Accumulation of these host-derived factors are 


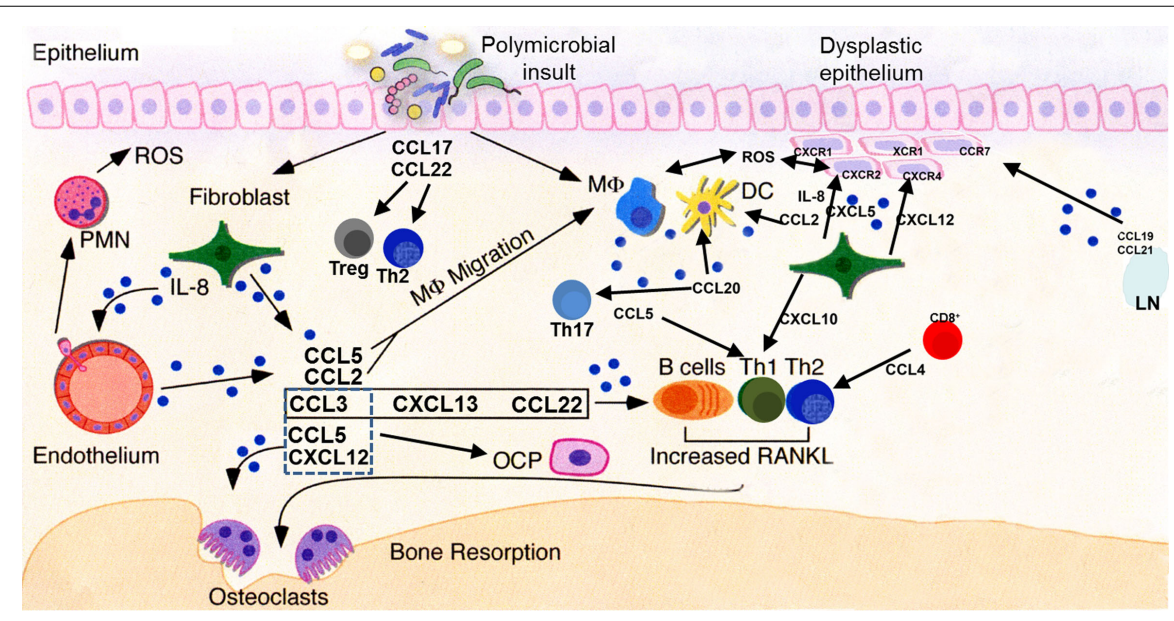

FIGURE 4 | Key chemokine functionalities in periodontitis and oral carcinogenesis. A dysbiotic oral microflora triggers inflammatory processes in the oral epithelium. Release of chemokines, among other molecules, results in progression (or suppression, in some cases) of the inflammatory process and stimulation of both innate and adaptive immune responses through recruitment of cellular mediators. Persistent inflammation extends deeper into the tissues, subsequently leading to osteoclast activation and subsequent destruction of alveolar bone. Multiple chemokines involved in the periodontal inflammatory process may stimulate their cognate receptors present on normal, dysplastic, or malignant epithelial cells, deregulating cellular growth, and promoting the motile phenotype. Pro-angiogenic chemokines, such as IL-8 and CXCL5, act upon endothelial cells to promote neovascularization of developing tumors. $L N$, lymph node; ROS, reactive oxygen species; PMN, neutrophil polymorph; OCP, osteoclast precursor; DC, dendritic cell; $M \Phi$, macrophage. likely to modulate the tumor microenvironment by causing DNA damage, promoting epigenetic and genetic alterations, increasing angiogenesis, cell survival, proliferation, migration, and inhibiting apoptosis. Altered cells may eventually promote production of more inflammatory mediators, further enhancing inflammation thereby contributing to cancer pathogenesis (Figure 3). Still, the role of TLRs in cancer is ambiguous, as they can either mediate signaling leading to inhibition of apoptosis and altered cell proliferation, or trigger immune responses to cancer. While the observations outlined above provide some evidence for plausible mechanisms linking cancer and periodontal inflammation, future studies are warranted to delineate the specific cellular and molecular pathways that may precipitate tumorigenesis in the oral cavity.

\section{Concluding Remarks}

Emerging evidence argues that mutual interactions between host cells and the oral microbiome (bacteria and/or viruses) in the course of chronic periodontal inflammation likely creates a tumor-favorable microenvironment that may promote cancer development and progression (Figure 4). However, studies of the biological and biochemical mechanisms to explain the observed associations between oral cancer and periodontitis are at an early stage, and future investigations are warranted to determine the etiology and to delineate the molecular pathways involved. While the studies are underway exploring the possible cause-effect relationship between periodontal inflammation and oral cancer, it

\section{References}

1. Coussens LM, Werb Z. Inflammation and cancer. Nature (2002) 420(6917):860-7. doi:10.1038/nature01322

2. Hanahan D, Weinberg RA. Hallmarks of cancer: the next generation. Cell (2011) 144(5):646-74. doi:10.1016/j.cell.2011.02.013 is imperative for health care professionals to make their patients aware of the current evidence that there might be a link between periodontal disease and cancer development. Thus, maintaining good oral health should be considered as part of a healthy lifestyle, not only to prevent tooth loss but also for overall systemic health. Individuals who exhibit periodontal disease and who also have other risk factors related to their lifestyle or family history may benefit from more frequent periodontal maintenance visits to help maintain the infection and inflammation at a minimal level. In general, patients should be encouraged to adopt positive lifestyle habits such as regular physical and dental visits, meticulous oral hygiene, cessation of smoking, healthy eating habits, regular exercise, and elimination of other risks that may predispose to malignant transformation. It is also imperative for dental and medical professionals to communicate with each other and work as a team to manage their patients and reduce or eliminate possible risks, resulting in better overall oral and systemic health.

\section{Acknowledgments}

The authors would like to thank Dr. Katie Crump for assistance with preparation of illustrations. Work in the authors' laboratories is supported by U.S. Public Health Service Grants DE022836, KL2TR000057-03, and UL1TR000058 to SES and 1R01DE024381 to WAY. The authors declare no potential conflicts of interest with respect to the authorship and/or publication of this article.

3. Lin WW, Karin M. A cytokine-mediated link between innate immunity, inflammation, and cancer. J Clin Invest (2007) 117(5):1175-83. doi:10.1172/ JCI31537

4. Moore MM, Chua W, Charles KA, Clarke SJ. Inflammation and cancer: causes and consequences. Clin Pharmacol Ther (2010) 87(4):504-8. doi:10.1038/clpt. 2009.254 
5. Colombo AP, Boches SK, Cotton SL, Goodson JM, Kent R, Haffajee AD, et al. Comparisons of subgingival microbial profiles of refractory periodontitis, severe periodontitis, and periodontal health using the human oral microbe identification microarray. J Periodontol (2009) 80(9):1421-32. doi:10.1902/ jop. 2009.090185

6. Duran-Pinedo AE, Chen T, Teles R, Starr JR, Wang X, Krishnan K, et al. Community-wide transcriptome of the oral microbiome in subjects with and without periodontitis. ISME J (2014) 8(8):1659-72. doi:10.1038/ismej.2014.23

7. Teles R, Teles F, Frias-Lopez J, Paster B, Haffajee A. Lessons learned and unlearned in periodontal microbiology. Periodontol 2000 (2013) 62(1):95-162. doi:10.1111/prd.12010

8. Benakanakere M, Abdolhosseini M, Hosur K, Finoti LS, Kinane DF. TLR2 promoter hypermethylation creates innate immune dysbiosis. J Dent Res (2015) 94(1):183-91. doi:10.1177/0022034514557545

9. Bullon P, Newman HN, Battino M. Obesity, diabetes mellitus, atherosclerosis and chronic periodontitis: a shared pathology via oxidative stress and mitochondrial dysfunction? Periodontol 2000 (2014) 64(1):139-53. doi:10.1111/j. 1600-0757.2012.00455.x

10. Doyle CJ, Bartold PM. How does stress influence periodontitis? J Int Acad Periodontol (2012) 14(2):42-9.

11. Johannsen A, Susin C, Gustafsson A. Smoking and inflammation: evidence for a synergistic role in chronic disease. Periodontol 2000 (2014) 64(1):111-26. doi:10.1111/j.1600-0757.2012.00456.x

12. Rhodin K, Divaris K, North KE, Barros SP, Moss K, Beck JD, et al. Chronic periodontitis genome-wide association studies: gene-centric and gene set enrichment analyses. J Dent Res (2014) 93(9):882-90. doi:10.1177/ 0022034514544506

13. Zhang S, Barros SP, Moretti AJ, Yu N, Zhou J, Preisser JS, et al. Epigenetic regulation of TNFA expression in periodontal disease. J Periodontol (2013) 84(11):1606-16. doi:10.1902/jop.2013.120294

14. Eke PI, Dye BA, Wei L, Slade GD, Thornton-Evans GO, Borgnakke WS, et al. Update on prevalence of periodontitis in adults in the United States: NHANES 2009-2012. J Periodontol (2015) 86(5):611-22. doi:10.1902/jop.2015.140520

15. Hajishengallis G. Periodontitis: from microbial immune subversion to systemic inflammation. Nat Rev Immunol (2015) 15(1):30-44. doi:10.1038/ nri3785

16. Han YW, Houcken W, Loos BG, Schenkein HA, Tezal M. Periodontal disease, atherosclerosis, adverse pregnancy outcomes, and head-and-neck cancer. Adv Dent Res (2014) 26(1):47-55. doi:10.1177/0022034514528334

17. Han YW, Wang X. Mobile microbiome: oral bacteria in extra-oral infections and inflammation. J Dent Res (2013) 92(6):485-91. doi:10.1177/ 0022034513487559

18. Ide M, Papapanou PN. Epidemiology of association between maternal periodontal disease and adverse pregnancy outcomes-systematic review. J Periodontol (2013) 84(4 Suppl):S181-94. doi:10.1902/jop.2013.134009

19. Lalla E, Papapanou PN. Diabetes mellitus and periodontitis: a tale of two common interrelated diseases. Nat Rev Endocrinol (2011) 7(12):738-48. doi:10. 1038/nrendo.2011.106

20. Linden GJ, Lyons A, Scannapieco FA. Periodontal systemic associations: review of the evidence. J Periodontol (2013) 84(4 Suppl):S8-19. doi:10.1902/ jop.2013.1340010

21. Schenkein HA, Loos BG. Inflammatory mechanisms linking periodontal diseases to cardiovascular diseases. J Periodontol (2013) 84(4 Suppl):S51-69. doi:10.1902/jop.2013.134006

22. Fitzpatrick SG, Katz J. The association between periodontal disease and cancer: a review of the literature. J Dent (2010) 38(2):83-95. doi:10.1016/j.jdent.2009. 10.007

23. Yao QW, Zhou DS, Peng HJ, Ji P, Liu DS. Association of periodontal disease with oral cancer: a meta-analysis. Tumour Biol (2014) 35(7):7073-7. doi:10. 1007/s13277-014-1951-8

24. Hajishengallis G. Immunomicrobial pathogenesis of periodontitis: keystones, pathobionts, and host response. Trends Immunol (2014) 35(1):3-11. doi:10. 1016/j.it.2013.09.001

25. Kinane DF. Causation and pathogenesis of periodontal disease. Periodontol 2000 (2001) 25:8-20. doi:10.1034/j.1600-0757.2001.22250102.x

26. The Cancer Genome Atlas Network. Comprehensive genomic characterization of head and neck squamous cell carcinomas. Nature (2015) 517(7536):576-82. doi:10.1038/nature14129
27. Mager DL, Haffajee AD, Devlin PM, Norris CM, Posner MR, Goodson JM The salivary microbiota as a diagnostic indicator of oral cancer: a descriptive, non-randomized study of cancer-free and oral squamous cell carcinoma subjects. J Transl Med (2005) 3(1):27. doi:10.1186/1479-5876-3-27

28. Nagy KN, Sonkodi I, Szoke I, Nagy E, Newman HN. The microflora associated with human oral carcinomas. Oral Oncol (1998) 34(4):304-8. doi:10.1016/ S1368-8375(98)00008-6

29. Silva TA, Garlet GP, Fukada SY, Silva JS, Cunha FQ. Chemokines in oral inflammatory diseases: apical periodontitis and periodontal disease. J Dent Res (2007) 86(4):306-19. doi:10.1177/154405910708600403

30. Graves DT. The potential role of chemokines and inflammatory cytokines in periodontal disease progression. Clin Infect Dis (1999) 28(3):482-90. doi:10. $1086 / 515178$

31. Ertugrul AS, Sahin H, Dikilitas A, Alpaslan N, Bozoglan A. Comparison of CCL28, interleukin-8, interleukin-1beta and tumor necrosis factor-alpha in subjects with gingivitis, chronic periodontitis and generalized aggressive periodontitis. J Periodontal Res (2013) 48(1):44-51. doi:10.1111/j.1600-0765. 2012.01500.x

32. Gamonal J, Acevedo A, Bascones A, Jorge O, Silva A. Levels of interleukin-1 beta, -8 , and -10 and RANTES in gingival crevicular fluid and cell populations in adult periodontitis patients and the effect of periodontal treatment J Periodontol (2000) 71(10):1535-45. doi:10.1902/jop.2000.71.10.1535

33. Mathur A, Michalowicz B, Castillo M, Aeppli D. Interleukin-1 alpha, interleukin-8 and interferon-alpha levels in gingival crevicular fluid. J Periodontal Res (1996) 31(7):489-95. doi:10.1111/j.1600-0765.1996.tb01414.x

34. Payne JB, Reinhardt RA, Masada MP, DuBois LM, Allison AC. Gingival crevicular fluid IL-8: correlation with local IL-1 beta levels and patient estrogen status. J Periodontal Res (1993) 28(6 Pt 1):451-3.

35. Souto GR, Queiroz-Junior CM, Costa FO, Mesquita RA. Smoking effect on chemokines of the human chronic periodontitis. Immunobiology (2014) 219(8):633-6. doi:10.1016/j.imbio.2014.03.014

36. Souto GR, Queiroz-Junior CM, de Abreu MH, Costa FO, Mesquita RA. Proinflammatory, Th1, Th2, Th17 cytokines and dendritic cells: a cross-sectional study in chronic periodontitis. PLoS One (2014) 9(3):e91636. doi:10.1371/ journal.pone.0091636

37. Darveau RP, Belton CM, Reife RA, Lamont RJ. Local chemokine paralysis, a novel pathogenic mechanism for Porphyromonas gingivalis. Infect Immun (1998) 66(4):1660-5.

38. Fujita $Y$, Nakayama $M$, Naito $M$, Yamachika E, Inoue $T$, Nakayama $K$, et al. Hemoglobin receptor protein from Porphyromonas gingivalis induces interleukin-8 production in human gingival epithelial cells through stimulation of the mitogen-activated protein kinase and NF-kappaB signal transduction pathways. Infect Immun (2014) 82(1):202-11. doi:10.1128/IAI.01140-12

39. Hutcherson JA, Bagaitkar J, Nagano K, Yoshimura F, Wang H, Scott DA. Porphyromonas gingivalis RagB is a proinflammatory signal transducer and activator of transcription 4 agonist. Mol Oral Microbiol (2014). doi:10.1111/ omi.12089

40. Sahingur SE, Xia XJ, Schifferle RE. Oral bacterial DNA differ in their ability to induce inflammatory responses in human monocytic cell lines. J Periodontol (2012) 83(8):1069-77. doi:10.1902/jop.2011.110522

41. Stathopoulou PG, Benakanakere MR, Galicia JC, Kinane DF. Epithelial cell pro-inflammatory cytokine response differs across dental plaque bacterial species. J Clin Periodontol (2010) 37(1):24-9. doi:10.1111/j.1600-051X.2009. 01505.x

42. Takeuchi H, Hirano T, Whitmore SE, Morisaki I, Amano A, Lamont RJ. The serine phosphatase SerB of Porphyromonas gingivalis suppresses IL-8 production by dephosphorylation of NF-kappaB RelA/p65. PLoS Pathog (2013) 9(4):e1003326. doi:10.1371/journal.ppat.1003326

43. Bendre MS, Montague DC, Peery T, Akel NS, Gaddy D, Suva LJ. Interleukin8 stimulation of osteoclastogenesis and bone resorption is a mechanism for the increased osteolysis of metastatic bone disease. Bone (2003) 33(1):28-37. doi:10.1016/S8756-3282(03)00086-3

44. Yang L, Zhu X, Liang X, Ling Z, Li R. Association of IL-8-251A $>$ T polymorphisms with oral cancer risk: evidences from a meta-analysis. Tumor Biol (2014) 35(9):9211-8. doi:10.1007/s13277-014-2193-5

45. Wang Z, Wang C, Zhao Z, Liu F, Guan X, Lin X, et al. Association between $-251 \mathrm{~A}>\mathrm{T}$ polymorphism in the interleukin- 8 gene and oral cancer risk: a meta-analysis. Gene (2013) 522(2):168-76. doi:10.1016/j.gene.2013.03.066 
46. Hosokawa Y, Hosokawa I, Ozaki K, Nakae H, Matsuo T. Cytokines differentially regulate CXCL10 production by interferon-gamma-stimulated or tumor necrosis factor-alpha-stimulated human gingival fibroblasts. J Periodontal Res (2009) 44(2):225-31. doi:10.1111/j.1600-0765.2008.01124.x

47. Emingil G, Atilla G, Baskesen A, Berdeli A. Gingival crevicular fluid EMAP-II, MIP-1alpha and MIP-1beta levels of patients with periodontal disease. J Clin Periodontol (2005) 32(8):880-5. doi:10.1111/j.1600-051X.2005. 00780.x

48. Emingil G, Atilla G, Huseyinov A. Gingival crevicular fluid monocyte chemoattractant protein-1 and RANTES levels in patients with generalized aggressive periodontitis. J Clin Periodontol (2004) 31(10):829-34. doi:10.1111/ j.1600-051X.2004.00584.x

49. Kurtis B, Tuter G, Serdar M, Akdemir P, Uygur C, Firatli E, et al. Gingival crevicular fluid levels of monocyte chemoattractant protein-1 and tumor necrosis factor-alpha in patients with chronic and aggressive periodontitis. J Periodontol (2005) 76(11):1849-55. doi:10.1902/jop.2005.76.11.1849

50. Souto GR, Queiroz CM Jr, Costa FO, Mesquita RA. Relationship between chemokines and dendritic cells in human chronic periodontitis. J Periodontol (2014) 85(10):1416-23. doi:10.1902/jop.2014.130662

51. Hosokawa Y, Hosokawa I, Shindo S, Ozaki K, Matsuo T. IL-22 enhances CCL20 production in IL-1beta-stimulated human gingival fibroblasts. Inflammation (2014) 37(6):2062-6. doi:10.1007/s10753-014-9939-5

52. Hosokawa Y, Shindo S, Hosokawa I, Ozaki K, Matsuo T. IL-6 transsignaling enhances CCL20 production from IL-1beta-stimulated human periodontal ligament cells. Inflammation (2014) 37(2):381-6. doi:10.1007/ s10753-013-9750-8

53. Imai $T$, Baba $M$, Nishimura $M$, Kakizaki $M$, Takagi $S$, Yoshie O. The $T$ cell-directed cc chemokine tarc is a highly specific biological ligand for CC Chemokine receptor 4. J Biol Chem (1997) 272(23):15036-42. doi:10.1074/jbc. 272.23.15036

54. Imai T, Chantry D, Raport CJ, Wood CL, Nishimura M, Godiska R, et al. Macrophage-derived chemokine is a functional ligand for the CC chemokine receptor 4. J Biol Chem (1998) 273(3):1764-8. doi:10.1074/jbc.273.3.1764

55. Hosokawa Y, Hosokawa I, Ozaki K, Nakae H, Matsuo T. CC chemokine ligand 17 in periodontal diseases: expression in diseased tissues and production by human gingival fibroblasts. J Periodontal Res (2008) 43(4):471-7. doi:10.1111/ j.1600-0765.2007.01080.x

56. Yeudall WA, Miyazaki H. Chemokines and squamous cancer of the head and neck: targets for therapeutic intervention? Expert Rev Anticancer Ther (2007) 7(3):351-60. doi:10.1586/14737140.7.3.351

57. Metzner B, Hofmann C, Heinemann C, Zimpfer U, Schraufstatter I, Schopf E, et al. Overexpression of CXC-chemokines and CXC-chemokine receptor type II constitute an autocrine growth mechanism in the epidermoid carcinoma cells KB and A431. Oncol Rep (1999) 6(6):1405-10.

58. Christofakis EP, Miyazaki H, Rubink DS, Yeudall WA. Roles of CXCL8 in squamous cell carcinoma proliferation and migration. Oral Oncol (2008) 44:920-6. doi:10.1016/j.oraloncology.2007.12.002

59. Spielmann N, Wong DT. Saliva: diagnostics and therapeutic perspectives. Oral Dis (2011) 17(4):345-54. doi:10.1111/j.1601-0825.2010.01773.x

60. Miyazaki H, Patel V, Wang H, Edmunds RK, Gutkind JS, Yeudall WA. Downregulation of CXCL5 inhibits squamous carcinogenesis. Cancer Res (2006) 66(8):4279-84. doi:10.1158/0008-5472.CAN-05-4398

61. Khurram SA, Bingle L, McCabe BM, Farthing PM, Whawell SA. The chemokine receptors CXCR1 and CXCR2 regulate oral cancer cell behaviour. J Oral Pathol Med (2014) 43(9):667-74. doi:10.1111/jop.12191

62. Delilbasi CB, Okura M, Iida S, Kogo M. Investigation of CXCR4 in squamous cell carcinoma of the tongue. Oral Oncol (2004) 40(2):154-7. doi:10.1016/ S1368-8375(03)00144-1

63. Muller A, Homey B, Soto H, Ge N, Catron D, Buchanan ME, et al. Involvement of chemokine receptors in breast cancer metastasis. Nature (2001) 410(6824):50-6. doi:10.1038/35065016

64. Takabayashi T, Takahashi N, Okamoto M, Yagi H, Sato M, Fujieda S. Lipopolysaccharides increase the amount of CXCR4, and modulate the morphology and invasive activity of oral cancer cells in a CXCL12-dependent manner. Oral Oncol (2009) 45(11):968-73. doi:10.1016/j.oraloncology.2009. 06.006

65. Rehman AO, Wang CY. SDF-1alpha promotes invasion of head and neck squamous cell carcinoma by activating NF-kappaB. J Biol Chem (2008) 283(29):19888-94. doi:10.1074/jbc.M710432200
66. Rehman AO, Wang CY. CXCL12/SDF-1 alpha activates NF-kappaB and promotes oral cancer invasion through the Carma3/Bcl10/Malt1 complex. Int J Oral Sci (2009) 1(3):105-18. doi:10.4248/IJOS.09059

67. Tang CH, Chuang JY, Fong YC, Maa MC, Way TD, Hung CH. Bone-derived SDF-1 stimulates IL-6 release via CXCR4, ERK and NF-kappaB pathways and promotes osteoclastogenesis in human oral cancer cells. Carcinogenesis (2008) 29(8):1483-92. doi:10.1093/carcin/bgn045

68. Oue E, Lee JW, Sakamoto K, Iimura T, Aoki K, Kayamori K, et al. CXCL2 synthesized by oral squamous cell carcinoma is involved in cancer-associated bone destruction. Biochem Biophys Res Commun (2012) 424(3):456-61. doi:10. 1016/j.bbrc.2012.06.132

69. Hromas R, Broxmeyer HE, Kim C, Nakshatri H, Christopherson K II, Azam $\mathrm{M}$, et al. Cloning of BRAK, a novel divergent CXC chemokine preferentially expressed in normal versus malignant cells. Biochem Biophys Res Commun (1999) 255(3):703-6. doi:10.1006/bbrc.1999.0257

70. Frederick MJ, Henderson Y, Xu X, Deavers MT, Sahin AA, Wu H, et al In vivo expression of the novel CXC chemokine BRAK in normal and cancerous human tissue. Am J Pathol (2000) 156(6):1937-50. doi:10.1016/ S0002-9440(10)65067-5

71. Ozawa S, Kato Y, Komori R, Maehata Y, Kubota E, Hata R. BRAK/CXCL14 expression suppresses tumor growth in vivo in human oral carcinoma cells. Biochem Biophys Res Commun (2006) 348(2):406-12. doi:10.1016/j.bbrc.2006. 07.070

72. Ozawa S, Kato Y, Kubota E, Hata R. BRAK/CXCL14 expression in oral carcinoma cells completely suppresses tumor cell xenografts in SCID mouse. Biomed Res (2009) 30(5):315-8. doi:10.2220/biomedres.30.315

73. Wang J, Xi L, Hunt JL, Gooding W, Whiteside TL, Chen Z, et al. Expression pattern of chemokine receptor 6 (CCR6) and CCR7 in squamous cell carcinoma of the head and neck identifies a novel metastatic phenotype. Cancer Res (2004) 64(5):1861-6. doi:10.1158/0008-5472.CAN-03-2968

74. Chuang JY, Yang WH, Chen HT, Huang CY, Tan TW, Lin YT, et al. CCL5/CCR5 axis promotes the motility of human oral cancer cells. J Cell Physiol (2009) 220(2):418-26. doi:10.1002/jcp.21783

75. Li X, Xu Q, Wu Y, Li J, Tang D, Han L, et al. A CCL2/ROS autoregulation loop is critical for cancer-associated fibroblasts-enhanced tumor growth of oral squamous cell carcinoma. Carcinogenesis (2014) 35(6):1362-70. doi:10.1093/ carcin/bgu046

76. Khurram SA, Whawell SA, Bingle L, Murdoch C, McCabe BM, Farthing PM Functional expression of the chemokine receptor XCR1 on oral epithelial cells. J Pathol (2010) 221(2):153-63. doi:10.1002/path.2695

77. Balkwill F, Charles KA, Mantovani A. Smoldering and polarized inflammation in the initiation and promotion of malignant disease. Cancer Cell (2005) 7(3):211-7. doi:10.1016/j.ccr.2005.02.013

78. Mantovani A, Allavena P, Sica A, Balkwill F. Cancer-related inflammation. Nature (2008) 454(7203):436-44. doi:10.1038/nature07205

79. Mai X, LaMonte MJ, Hovey KM, Nwizu N, Freudenheim JL, Tezal M, et al. History of periodontal disease diagnosis and lung cancer incidence in the Women's Health Initiative Observational Study. Cancer Causes Control (2014) 25(8):1045-53. doi:10.1007/s10552-014-0405-3

80. Meyer MS, Joshipura K, Giovannucci E, Michaud DS. A review of the relationship between tooth loss, periodontal disease, and cancer. Cancer Causes Control (2008) 19(9):895-907. doi:10.1007/s10552-008-9163-4

81. Tezal M, Sullivan MA, Reid ME, Marshall JR, Hyland A, Loree T, et al. Chronic periodontitis and the risk of tongue cancer. Arch Otolaryngol Head Neck Surg (2007) 133(5):450-4. doi:10.1001/archotol.133.5.450

82. Tezal M, Sullivan MA, Hyland A, Marshall JR, Stoler D, Reid ME, et al Chronic periodontitis and the incidence of head and neck squamous cell carcinoma. Cancer Epidemiol Biomarkers Prev (2009) 18(9):2406-12. doi:10. 1158/1055-9965.EPI-09-0334

83. Tezal M, Sullivan Nasca M, Stoler DL, Melendy T, Hyland A, Smaldino PJ, et al. Chronic periodontitis-human papillomavirus synergy in base of tongue cancers. Arch Otolaryngol Head Neck Surg (2009) 135(4):391-6. doi:10.1001/ archoto. 2009.6

84. Tezal M, Grossi SG, Ho AW, Genco RJ. The effect of alcohol consumption on periodontal disease. J Periodontol (2001) 72(2):183-9. doi:10.1902/jop.2001. 72.2 .183

85. Bundgaard T, Wildt J, Frydenberg M, Elbrond O, Nielsen JE. Case-control study of squamous cell cancer of the oral cavity in Denmark. Cancer Causes Control (1995) 6(1):57-67. doi:10.1007/BF00051681 
86. Rezende CP, Ramos MB, Daguila CH, Dedivitis RA, Rapoport A. Oral health changes in with oral and oropharyngeal cancer. Braz J Otorhinolaryngol (2008) 74(4):596-600.

87. Garrote LF, Herrero R, Reyes RM, Vaccarella S, Anta JL, Ferbeye L, et al. Risk factors for cancer of the oral cavity and oro-pharynx in Cuba. $\mathrm{Br} J$ Cancer (2001) 85(1):46-54. doi:10.1054/bjoc.2000.1825

88. Hiraki A, Matsuo K, Suzuki T, Kawase T, Tajima K. Teeth loss and risk of cancer at 14 common sites in Japanese. Cancer Epidemiol Biomarkers Prev (2008) 17(5):1222-7. doi:10.1158/1055-9965.EPI-07-2761

89. Marshall JR, Graham S, Haughey BP, Shedd D, O'Shea R, Brasure J, et al. Smoking, alcohol, dentition and diet in the epidemiology of oral cancer. Eur Journal Cancer B Oral Oncol (1992) 28B(1):9-15. doi:10.1016/0964-1955(92) 90005-L

90. Michaud DS, Liu Y, Meyer M, Giovannucci E, Joshipura K. Periodontal disease, tooth loss, and cancer risk in male health professionals: a prospective cohort study. Lancet Oncol (2008) 9(6):550-8. doi:10.1016/S1470-2045(08) 70106-2

91. Rosenquist K, Wennerberg J, Schildt EB, Bladstrom A, Goran Hansson B, Andersson G. Oral status, oral infections and some lifestyle factors as risk factors for oral and oropharyngeal squamous cell carcinoma. A populationbased case-control study in southern Sweden. Acta Otolaryngol (2005) 125(12):1327-36. doi:10.1080/00016480510012273

92. Tezal M, Grossi SG, Genco RJ. Is periodontitis associated with oral neoplasms? J Periodontol (2005) 76(3):406-10. doi:10.1902/jop.2005.76.3.406

93. Tezal M, Scannapieco FA, Wactawski-Wende J, Hyland A, Marshall JR, Rigual $\mathrm{NR}$, et al. Local inflammation and human papillomavirus status of head and neck cancers. Arch Otolaryngol Head Neck Surg (2012) 138(7):669-75. doi:10. 1001/archoto. 2012.873

94. Wen BW, Tsai CS, Lin CL, Chang YJ, Lee CF, Hsu CH, et al. Cancer risk among gingivitis and periodontitis patients: a nationwide cohort study. QJM (2014) 107(4):283-90. doi:10.1093/qjmed/hct248

95. Zheng TZ, Boyle P, Hu HF, Duan J, Jian PJ, Ma DQ, et al. Dentition, oral hygiene, and risk of oral cancer: a case-control study in Beijing, People's Republic of China. Cancer Causes Control (1990) 1(3):235-41. doi:10.1007/ BF00117475

96. La Vecchia C, Tavani A, Franceschi S, Levi F, Corrao G, Negri E. Epidemiology and prevention of oral cancer. Oral Oncol (1997) 33(5):302-12. doi:10.1016/ S1368-8375(97)00029-8

97. Llewellyn CD, Johnson NW, Warnakulasuriya KA. Risk factors for oral cancer in newly diagnosed patients aged 45 years and younger: a case-control study in Southern England. J Oral Pathol Med (2004) 33(9):525-32. doi:10.1111/j. 1600-0714.2004.00222.x

98. Adler-Storthz K, Newland JR, Tessin BA, Yeudall WA, Shillitoe EJ. Human papillomavirus type 2 DNA in oral verrucous carcinoma. J Oral Pathol (1986) 15(9):472-5. doi:10.1111/j.1600-0714.1986.tb00661.x

99. Scully C, Maitland NJ, Cox MF, Prime SS. Human papillomavirus DNA and oral mucosa. Lancet (1987) 1(8528):336. doi:10.1016/S0140-6736(87)92073-3

100. Yeudall WA. Human papillomaviruses and oral neoplasia. Eur J Cancer B Oral Oncol (1992) 28B(1):61-6. doi:10.1016/0964-1955(92)90015-S

101. Sugerman PB, Shillitoe EJ. The high risk human papillomaviruses and oral cancer: evidence for and against a causal relationship. Oral Dis (1997) 3(3):130-47. doi:10.1111/j.1601-0825.1997.tb00025.x

102. Snijders PJ, Cromme FV, van den Brule AJ, Schrijnemakers HF, Snow GB, Meijer CJ, et al. Prevalence and expression of human papillomavirus in tonsillar carcinomas, indicating a possible viral etiology. Int J Cancer (1992) 51(6):845-50. doi:10.1002/ijc.2910510602

103. Wilczynski SP, Lin BT, Xie Y, Paz IB. Detection of human papillomavirus DNA and oncoprotein overexpression are associated with distinct morphological patterns of tonsillar squamous cell carcinoma. Am J Pathol (1998) 152(1):145-56.

104. Gillison ML, Koch WM, Capone RB, Spafford M, Westra WH, Wu L, et al. Evidence for a causal association between human papillomavirus and a subset of head and neck cancers. J Natl Cancer Inst (2000) 92(9):709-20. doi:10.1093/ jnci/92.9.709

105. Kreimer AR, Clifford GM, Boyle P, Franceschi S. Human papillomavirus types in head and neck squamous cell carcinomas worldwide: a systematic review. Cancer Epidemiol Biomarkers Prev (2005) 14(2):467-75. doi:10.1158/ 1055-9965.EPI-04-0551
106. Singer C. A study of some factors in the aetiology of oral carcinoma. Q J Med (1911) 5:15-57.

107. Lund CL. Syphilis in relation to cancer of the buccal mucosa. N Engl J Med (1933) 209:131-4. doi:10.1056/NEJM193307202090302

108. Dickenson AJ, Currie WJ, Avery BS. Screening for syphilis in patients with carcinoma of the tongue. Br J Oral Maxillofac Surg (1995) 33(5):319-20. doi:10.1016/0266-4356(95)90046-2

109. Maier H, Zoller J, Herrmann A, Kreiss M, Heller WD. Dental status and oral hygiene in patients with head and neck cancer. Otolaryngol Head Neck Surg (1993) 108(6):655-61.

110. Velly AM, Franco EL, Schlecht N, Pintos J, Kowalski LP, Oliveira BV, et al. Relationship between dental factors and risk of upper aerodigestive tract cancer. Oral Oncol (1998) 34(4):284-91. doi:10.1016/S1368-8375(98)00003-7

111. O’Mahony R, Vaira D, Holton J, Basset C. Helicobacter pylori: current status and future prospects. Sci Prog (2004) 87(Pt 4):269-96. doi:10.3184/ 003685004783238481

112. Houghton J, Wang TC. Helicobacter pylori and gastric cancer: a new paradigm for inflammation-associated epithelial cancers. Gastroenterology (2005) 128(6):1567-78. doi:10.1053/j.gastro.2005.03.037

113. Chu SH, Kim H, Seo JY, Lim JW, Mukaida N, Kim KH. Role of NF-kappaB and AP-1 on Helicobater pylori-induced IL-8 expression in AGS cells. Dig Dis Sci (2003) 48(2):257-65. doi:10.1023/A:1021963007225

114. Joh T, Kataoka H, Tanida S, Watanabe K, Ohshima T, Sasaki M, et al. Helicobacter pylori-stimulated interleukin-8 (IL-8) promotes cell proliferation through transactivation of epidermal growth factor receptor (EGFR) by disintegrin and metalloproteinase (ADAM) activation. Dig Dis Sci (2005) 50(11):2081-9. doi:10.1007/s10620-005-3011-0

115. Balkwill F. Cancer and the chemokine network. Nat Rev Cancer (2004) 4(7):540-50. doi:10.1038/nrc1388

116. Fujita Y, Okamoto M, Goda H, Tano T, Nakashiro K, Sugita A, et al. Prognostic significance of interleukin-8 and CD163-positive cell-infiltration in tumor tissues in patients with oral squamous cell carcinoma. PLoS One (2014) 9(12):e110378. doi:10.1371/journal.pone.0110378

117. Ohnishi T, Daikuhara Y. Hepatocyte growth factor/scatter factor in development, inflammation and carcinogenesis: its expression and role in oral tissues. Arch Oral Biol (2003) 48(12):797-804. doi:10.1016/S0003-9969(03)00180-8

118. Abiko Y, Nishimura M, Kusano K, Nakashima K, Okumura K, Arakawa T, et al. Expression of MIP-3alpha/CCL20, a macrophage inflammatory protein in oral squamous cell carcinoma. Arch Oral Biol (2003) 48(2):171-5. doi:10. 1016/S0003-9969(02)00167-X

119. Sakamoto H, Sasaki J, Nord CE. Association between bacterial colonization on the tumor, bacterial translocation to the cervical lymph nodes and subsequent postoperative infection in patients with oral cancer. Clin Microbiol Infect (1999) 5(10):612-6. doi:10.1111/j.1469-0691.1999.tb00417.x

120. Sakamoto H, Naito H, Ohta Y, Tanakna R, Maeda N, Sasaki J, et al. Isolation of bacteria from cervical lymph nodes in patients with oral cancer. Arch Oral Biol (1999) 44(10):789-93. doi:10.1016/S0003-9969(99)00079-5

121. Han YW. Fusobacterium nucleatum: a commensal-turned pathogen. Curr Opin Microbiol (2015) 23C:141-7. doi:10.1016/j.mib.2014.11.013

122. He J, Miyazaki H, Anaya C, Yu F, Yeudall WA, Lewis JP. Role of Porphyromonas gingivalis $\mathrm{FeoB} 2$ in metal uptake and oxidative stress protection. Infect Immun (2006) 74(7):4214-23. doi:10.1128/IAI.00014-06

123. Yilmaz O. The chronicles of Porphyromonas gingivalis: the microbium, the human oral epithelium and their interplay. Microbiology (2008) 154(Pt 10):2897-903. doi:10.1099/mic.0.2008/021220-0

124. Fujita T, Yoshimoto T, Matsuda S, Kajiya M, Kittaka M, Imai $H$, et al. Interleukin-8 induces DNA synthesis, migration and down-regulation of cleaved caspase- 3 in cultured human gingival epithelial cells. J Periodontal Res (2014). doi:10.1111/jre.12230

125. Mao S, Park Y, Hasegawa Y, Tribble GD, James CE, Handfield M, et al. Intrinsic apoptotic pathways of gingival epithelial cells modulated by Porphyromonas gingivalis. Cell Microbiol (2007) 9(8):1997-2007. doi:10.1111/j. 1462-5822.2007.00931.x

126. Moffatt CE, Lamont RJ. Porphyromonas gingivalis induction of microRNA-203 expression controls suppressor of cytokine signaling 3 in gingival epithelial cells. Infect Immun (2011) 79(7):2632-7. doi:10.1128/IAI.00082-11

127. Yao L, Jermanus C, Barbetta B, Choi C, Verbeke P, Ojcius DM, et al. Por phyromonas gingivalis infection sequesters pro-apoptotic Bad through Akt 
in primary gingival epithelial cells. Mol Oral Microbiol (2010) 25(2):89-101. doi:10.1111/j.2041-1014.2010.00569.x

128. Yilmaz O, Jungas T, Verbeke P, Ojcius DM. Activation of the phosphatidylinositol 3-kinase/Akt pathway contributes to survival of primary epithelial cells infected with the periodontal pathogen Porphyromonas gingivalis. Infect Immun (2004) 72(7):3743-51. doi:10.1128/IAI.72.7.3743-3751.2004

129. Lamont RJ, Hajishengallis G. Polymicrobial synergy and dysbiosis in inflammatory disease. Trends Mol Med (2015) 21(3):172-83. doi:10.1016/j.molmed. 2014.11.004

130. Inaba H, Sugita H, Kuboniwa M, Iwai S, Hamada M, Noda T, et al. Porphyromonas gingivalis promotes invasion of oral squamous cell carcinoma through induction of proMMP9 and its activation. Cell Microbiol (2014) 16(1):131-45. doi:10.1111/cmi.12211

131. Yee M, Kim S, Sethi P, Duzgunes N, Konopka K. Porphyromonas gingivalis stimulates IL-6 and IL-8 secretion in GMSM-K, HSC-3 and H413 oral epithelial cells. Anaerobe (2014) 28:62-7. doi:10.1016/j.anaerobe.2014.05.011

132. Jauregui CE, Wang Q, Wright CJ, Takeuchi H, Uriarte SM, Lamont RJ. Suppression of T-cell chemokines by Porphyromonas gingivalis. Infect Immun (2013) 81(7):2288-95. doi:10.1128/IAI.00264-13

133. Contreras A, Nowzari H, Slots J. Herpesviruses in periodontal pocket and gingival tissue specimens. Oral Microbiol Immunol (2000) 15(1):15-8. doi:10. 1034/j.1399-302x.2000.150103.x

134. Imai $\mathrm{K}$, Inoue $\mathrm{H}$, Tamura $\mathrm{M}$, Cueno ME, Takeichi $\mathrm{O}$, Kusama $\mathrm{K}$, et al. The periodontal pathogen Porphyromonas gingivalis induces the Epstein-Barr virus lytic switch transactivator ZEBRA by histone modification. Biochimie (2012) 94(3):839-46. doi:10.1016/j.biochi.2011.12.001

135. Kato A, Imai K, Ochiai K, Ogata Y. Higher prevalence of Epstein-Barr virus DNA in deeper periodontal pockets of chronic periodontitis in Japanese patients. PLoS One (2013) 8(8):e71990. doi:10.1371/journal.pone. 0071990

136. Kubar A, Saygun I, Ozdemir A, Yapar M, Slots J. Real-time polymerase chain reaction quantification of human cytomegalovirus and Epstein-Barr virus in periodontal pockets and the adjacent gingiva of periodontitis lesions. J Periodontal Res (2005) 40(2):97-104. doi:10.1111/j.1600-0765.2005. 00770.x

137. Slots J. Human viruses in periodontitis. Periodontol 2000 (2010) 53:89-110. doi:10.1111/j.1600-0757.2009.00325.x

138. Vincent-Bugnas S, Vitale S, Mouline CC, Khaali W, Charbit Y, Mahler P, et al. EBV infection is common in gingival epithelial cells of the periodontium and worsens during chronic periodontitis. PLoS One (2013) 8(12):e80336. doi:10.1371/journal.pone.0080336

139. Ahn MY, Kwon SM, Cheong HH, Park JH, Lee J, Min SK, et al. Toll-like receptor 7 agonist, imiquimod, inhibits oral squamous carcinoma cells through apoptosis and necrosis. J Oral Pathol Med (2012) 41(7):540-6. doi:10.1111/ j.1600-0714.2012.01158.x

140. Koga-Yamakawa E, Dovedi SJ, Murata M, Matsui H, Leishman AJ, Bell J, et al. Intratracheal and oral administration of SM-276001: a selective TLR7 agonist, leads to antitumor efficacy in primary and metastatic models of cancer. Int $J$ Cancer (2013) 132(3):580-90. doi:10.1002/ijc.27691

141. He Z, Huang X, Ni Y, Shi P, Wang Z, Han W, et al. Functional toll-like receptor 3 expressed by oral squamous cell carcinoma induced cell apoptosis and decreased migration. Oral Surg Oral Med Oral Pathol Oral Radiol (2014) 118(1):92-100. doi:10.1016/j.oooo.2014.03.012

142. Akira S. Innate immunity to pathogens: diversity in receptors for microbial recognition. Immunol Rev (2009) 227(1):5-8. doi:10.1111/j.1600-065X.2008. 00739.x

143. Asai Y, Ohyama Y, Gen K, Ogawa T. Bacterial fimbriae and their peptides activate human gingival epithelial cells through toll-like receptor 2. Infect Immun (2001) 69(12):7387-95. doi:10.1128/Iai.69.12.7387-7395.2001

144. Fischer H, Yamamoto M, Akira S, Beutler B, Svanborg C. Mechanism of pathogen-specific TLR4 activation in the mucosa: fimbriae, recognition receptors and adaptor protein selection. Eur J Immunol (2006) 36(2):267-77. doi:10. 1002/eji.200535149

145. Hou YF, Zhou YC, Zheng XX, Wang HY, Fu YL, Fang ZM, et al. Modulation of expression and function of Toll-like receptor 3 in A549 and H292 cells by histamine. Mol Immunol (2006) 43(12):1982-92. doi:10.1016/j.molimm.2005. 11.013

146. Kinane DF, Shiba H, Stathopoulou PG, Zhao H, Lappin DF, Singh A, et al. Gingival epithelial cells heterozygous for Toll-like receptor 4 polymorphisms
Asp299Gly and Thr399Ile are hypo-responsive to Porphyromonas gingivalis. Genes Immun (2006) 7(3):190-200. doi:10.1038/sj.gene.6364282

147. Lappin DF, Murad M, Sherrabeh S, Ramage G. Increased plasma levels epithelial cell-derived neutrophil-activating peptide 78/CXCL5 in periodontitis patients undergoing supportive therapy. J Clin Periodontol (2011) 38(10):887-93. doi:10.1111/j.1600-051X.2011.01757.x

148. Arenberg DA, Keane MP, DiGiovine B, Kunkel SL, Morris SB, Xue YY, et al. Epithelial-neutrophil activating peptide (ENA-78) is an important angiogenic factor in non-small cell lung cancer. JClin Invest (1998) 102(3):465-72. doi:10. $1172 / \mathrm{JCI} 3145$

149. Rich AM, Hussaini HM, Parachuru VP, Seymour GJ. Toll-like receptors and cancer, particularly oral squamous cell carcinoma. Front Immunol (2014) 5:464. doi:10.3389/fimmu.2014.00464

150. Beklen A, Hukkanen M, Richardson R, Konttinen YT. Immunohistochemical localization of Toll-like receptors 1-10 in periodontitis. Oral Microbiol Immunol (2008) 23(5):425-31. doi:10.1111/j.1399-302X.2008.00448.x

151. Kajita K, Honda T, Amanuma R, Domon H, Okui T, Ito H, et al. Quantitative messenger RNA expression of toll-like receptors and interferon-alphal in gingivitis and periodontitis. Oral Microbiol Immunol (2007) 22(6):398-402. doi:10.1111/j.1399-302X.2007.00377.x

152. Rojo-Botello NR, Garcia-Hernandez AL, Moreno-Fierros L. Expression of tolllike receptors 2, 4 and 9 is increased in gingival tissue from patients with type 2 diabetes and chronic periodontitis. J Periodontal Res (2012) 47(1):62-73. doi:10.1111/j.1600-0765.2011.01405.x

153. Sahingur SE, Xia XJ, Voth SC, Yeudall WA, Gunsolley JC. Increased nucleic acid receptor expression in chronic periodontitis. J Periodontol (2013) 84(10):e48-57. doi:10.1902/jop.2013.120739

154. Nonnenmacher C, Dalpke A, Zimmermann S, Flores-De-Jacoby L, Mutters R, Heeg K. DNA from periodontopathogenic bacteria is immunostimulatory for mouse and human immune cells. Infect Immun (2003) 71(2):850-6. doi:10. 1128/IAI.71.2.850-856.2003

155. Sahingur SE, Xia XJ, Alamgir S, Honma K, Sharma A, Schenkein HA. DNA from Porphyromonas gingivalis and Tannerella forsythia induce cytokine production in human monocytic cell lines. Mol Oral Microbiol (2010) 25(2):123-35. doi:10.1111/j.2041-1014.2009.00551.x

156. Sahingur SE, Xia X-J, Schifferle RE. Oral bacterial DNA differ in their ability to induce inflammatory responses in human monocytic cell lines. J Periodontol (2011) 83(8):1069-77. doi:10.1902/jop.2011.110522

157. Wara-aswapati N, Chayasadom A, Surarit R, Pitiphat W, Boch JA, Nagasawa $\mathrm{T}$, et al. Induction of toll-like receptor expression by Porphyromonas gingivalis. J Periodontol (2013) 84(7):1010-8. doi:10.1902/jop.2012.120362

158. Kotrashetti VS, Nayak R, Bhat K, Hosmani J, Somannavar P. Immunohistochemical expression of TLR4 and TLR9 in various grades of oral epithelial dysplasia and squamous cell carcinoma, and their roles in tumor progression: a pilot study. Biotech Histochem (2013) 88(6):311-22. doi:10.3109/10520295. 2013.785592

159. Ruan M, Zhang Z, Li S, Yan M, Liu S, Yang W, et al. Activation of toll-like receptor-9 promotes cellular migration via up-regulating MMP-2 expression in oral squamous cell carcinoma. PLoS One (2014) 9(3):e92748. doi:10.1371/ journal.pone.0092748

160. Ruan M, Thorn K, Liu S, Li S, Yang W, Zhang C, et al. The secretion of IL-6 by CpG-ODN-treated cancer cells promotes T-cell immune responses partly through the TLR-9/AP-1 pathway in oral squamous cell carcinoma. Int J Oncol (2014) 44(6):2103-10. doi:10.3892/ijo.2014.2356

161. Makinen LK, Atula T, Hayry V, Jouhi L, Datta N, Lehtonen S, et al. Predictive role of toll-like receptors 2,4 , and 9 in oral tongue squamous cell carcinoma. Oral Oncol (2015) 51(1):96-102. doi:10.1016/j.oraloncology.2014. 08.017

162. Brown J, Wang H, Hajishengallis GN, Martin M. TLR-signaling networks: an integration of adaptor molecules, kinases, and cross-talk. J Dent Res (2011) 90(4):417-27. doi:10.1177/0022034510381264

163. Bindhu OS, Ramadas K, Sebastian P, Pillai MR. High expression levels of nuclear factor kappa B and gelatinases in the tumorigenesis of oral squamous cell carcinoma. Head Neck (2006) 28(10):916-25. doi:10.1002/hed. 20437

164. Mishra A, Bharti AC, Varghese P, Saluja D, Das BC. Differential expression and activation of NF-kappaB family proteins during oral carcinogenesis: role of high risk human papillomavirus infection. Int J Cancer (2006) 119(12):2840-50. doi:10.1002/ijc.22262 
165. Sawhney M, Rohatgi N, Kaur J, Shishodia S, Sethi G, Gupta SD, et al. Expression of NF-kappaB parallels COX-2 expression in oral precancer and cancer: association with smokeless tobacco. Int J Cancer (2007) 120(12):2545-56. doi:10.1002/ijc.22657

166. Squarize CH, Castilho RM, Sriuranpong V, Pinto DS Jr, Gutkind JS. Molecular cross-talk between the NFkappaB and STAT3 signaling pathways in head and neck squamous cell carcinoma. Neoplasia (2006) 8(9):733-46. doi:10.1593/ neo.06274

167. Leeman RJ, Lui VW, Grandis JR. STAT3 as a therapeutic target in head and neck cancer. Expert Opin Biol Ther (2006) 6(3):231-41. doi:10.1517/14712598. 6.3.231

168. Santoni M, Massari F, Del Re M, Ciccarese C, Piva F, Principato G, et al. Investigational therapies targeting signal transducer and activator of transcription 3 for the treatment of cancer. Expert Opin Investig Drugs (2015):1-16. doi:10.1517/13543784.2015.1020370
169. Hsu K, Chung YM, Endoh Y, Geczy CL. TLR9 ligands induce S100A8 in macrophages via a STAT3-dependent pathway which requires IL-10 and PGE2. PLoS One (2014) 9(8):e103629. doi:10.1371/journal.pone.0103629

Conflict of Interest Statement: The authors declare that the research was conducted in the absence of any commercial or financial relationships that could be construed as a potential conflict of interest.

Copyright $(\odot 2015$ Sahingur and Yeudall. This is an open-access article distributed under the terms of the Creative Commons Attribution License (CC BY). The use, distribution or reproduction in other forums is permitted, provided the original author(s) or licensor are credited and that the original publication in this journal is cited, in accordance with accepted academic practice. No use, distribution or reproduction is permitted which does not comply with these terms. 